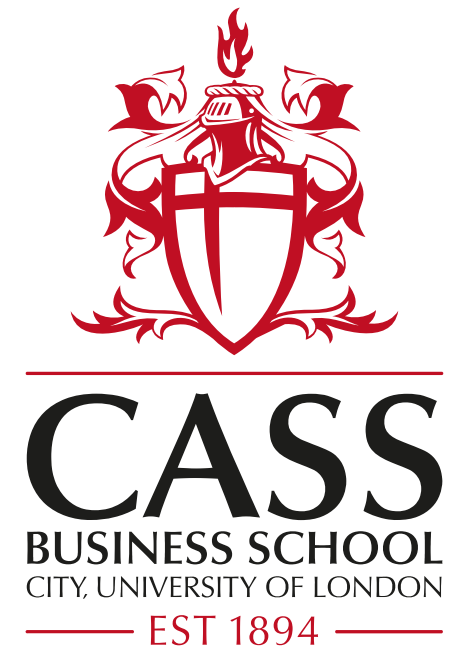

Centre for Banking Research

Cass Business School

City, University of London

\title{
Gender Diversity and Bank Misconduct
}

\author{
Francesca Arnaboldi \\ Barbara Casu \\ Angela Gallo \\ Elena Kalotychou \\ Anna Sarkisyan
}

January 2020

Centre for Banking Research Working Paper Series

WP 01/20 


\title{
Gender Diversity and Bank Misconduct
}

\author{
F. Arnaboldi, B. Casu, A. Gallo, E. Kalotychou, and A. Sarkisyan ${ }^{1}$
}

This version: January 2020

\begin{abstract}
This paper investigates whether gender-diverse boards can play a role in preventing costly bank misconduct episodes. We exploit the fines received by European banks from US regulators to reduce endogeneity issues related to supervisory and governance mechanisms. We show that greater female representation significantly reduces the frequency of misconduct fines, equivalent to savings of $\$ 7.48$ million per year. Female directors are more influential if they reach a critical mass and are supported by women in leadership roles. The mechanism through which gender diversity affects board effectiveness in preventing misconduct stems from the ethicality and risk aversion of the female directors, rather than their contribution to diversity. The findings are robust to alternative model specifications, proxies for gender diversity, reverse causality, country and bank controls, and sub-sample analyses.
\end{abstract}

Keywords: Misconduct; Gender diversity; Board of directors; Banks

JEL classification: M14, G21, G34

\footnotetext{
${ }^{1}$ F. Arnaboldi, Università degli Studi di Milano, email: farnaboldi@unimi.it; B. Casu, Cass Business School, City, University of London, email: b.casu@city.ac.uk; A. Gallo, Cass Business School, City, University of London, email: angela.gallo.1@ @ity.ac.uk; E. Kalotychou, Faculty of Management and Economics, Cyprus University of Technology, email: eleni.kalotychou@cut.ac.cy; A. Sarkisyan, Essex Business School, University of Essex, email: asarkisyan@essex.ac.uk.
} 


\section{Introduction}

Preventing bank misconduct is a top priority for international regulators and policymakers. In the years following the 2007-08 financial crisis, a larger than ever number of scandals and fraud episodes led to an unprecedented number of fines, globally. The world's largest banks were hit with misconduct fines amounting to $£ 264$ billion between 2012 and 2016 . $^{2}$ These misconduct episodes represent a threat not only to the soundness of individual financial institutions, as the fines associated with these investigations are high (in many cases exceeding $\$ 1$ billion), but they also represent a cost to society, harm financial stability, and decrease trust in the financial sector.

In this paper, we investigate the impact of board gender diversity on bank misconduct. Misconduct is typically associated with the wilful or intentional disregard of laws, ethics or internal governance and controls (ESRB, 2015). It can be linked to the violation of specific banking rules (for example, misselling of financial products) or the violation of general rules (for example, tax violations) and regulations related to the inappropriate supply of financial services (for example, anti-money laundering rules and economic sanctions). Misconduct issues frequently arise across markets and, correspondingly, occur more often in systemically important cross-border banks.

Misconduct episodes are often strictly intertwined with governance failures. Regulators have responded to the shortcomings of the existing bank governance structures with a series of initiatives aimed at reinforcing internal controls. Most of these proposals, from best practice guidelines to regulatory reforms, have placed an emphasis on increased diversity. In particular, regulators have focused on enhancing the gender diversity of the board of directors. The underlying idea is that the tone at the top shapes a firm's conduct and ethical climate and that more diverse boards, with an increased presence of women, would positively affect the governance of companies (Fields and Keys, 2003; Hermalin and Weisbach, 2003; Campbell and Minguez-Vera, 2008; Algan et al., 2016).

\footnotetext{
${ }^{2}$ Conduct Cost Project (CCP) Research Foundation (2017). Available at: http://conductcosts.ccpresearchfoundation.com
} 
There is a growing body of literature analysing whether corporate outcomes can be positively influenced by increased gender diversity in the boardroom and examining the governance mechanisms to achieve these potential benefits (Adams and Funk, 2009; Adams and Ferreira, 2009; Ahern and Dittmar, 2012; Liu et al., 2015). In this paper, we hypothesise that higher board gender diversity is associated with lower misconduct, proxied by the number of fines issued by US regulators to EU listed banks during 2007-18. We examine the post-crisis period, as regulators' attention increasingly focused on curbing risk-taking and potentially illegal practices. During this period, the activism of US regulators on European banks was exceptional both in reach and severity of fines. We aim to provide evidence on whether gender diversity, as a standalone feature or along other dimensions of diversity, increases board monitoring effectiveness and thus its ability to reduce conduct risk.

Establishing a causal relationship between board diversity and bank misconduct is challenging. In terms of identification, one of the main issues is the regulatory capture problem (Stigler, 1971), whereby regulatory agencies might be vulnerable to capture and thus less impartial and objective in imposing sanctions on domestic banks because of political connections, lobbying activities, or concerns about the financial stability of the domestic banking system. To address this issue, we focus on the sanctions imposed by US regulatory bodies on European listed banks. We exploit the fact that US regulators can impose fines not only on banks operating in the US, but their authority extends to all transactions which pass through the US financial system, including all US dollar-based transactions, both to US and non-US persons, entities, and institutions. ${ }^{3}$ As such, US sanctions are considered extraterritorial. ${ }^{4}$ To the extent that board members of our sample of European listed banks have no or weak influence on the outcome of US regulatory bodies' investigations, our empirical set up allows us to mitigate regulatory capture bias. US regulators have hit foreign financial institutions particularly hard over the last 10 years. Post-crisis, European banks have been fined four times more

\footnotetext{
${ }^{3}$ https://www.theglobaltreasurer.com/2018/10/18/sanctions-overview-eu-and-us-loan-markets/

${ }^{4}$ Recently, OFAC has targeted transactions conducted in US dollars even if they involve only non-US entities. For example, CSE, a telecom company from Singapore, was fined $\$ 12$ million for providing goods and services to Iranian energy projects. The dollar clearing process allows OFAC to claim US jurisdiction. See for the fine https://www.treasury.gov/resource-center/sanctions/CivPen/Documents/20170727_transtel.pdf and for the settlement https://www.treasury.gov/resource-center/sanctions/CivPen/Documents/transtel_settlement.pdf.
} 
than their US counterparts, representing 77 per cent of the total of all fines levied by US regulators since 2008 (Fenergo, 2018). Sanctions from US regulators have a more international echo and thus carry higher reputational risk. Furthermore, on average, US authorities impose larger financial penalties which can have a stronger impact on sanctioned banks' performance. Therefore, we expect a bank's board of directors to be particularly concerned about misconduct fines originating from the US and, more importantly, we expect the board to be more aware and active in monitoring potential sources of conduct risk.

Another challenge relates to the fact that board characteristics are not exogenous random variables but are endogenously chosen by firms (Hermalin and Weisbach, 2003; Adams and Ferreira, 2007; Sila et al., 2016). Two sources of endogeneity are potentially likely to bias our estimates of how board diversity affects bank misconduct: omitted variable bias and reverse causality. To address potential endogeneity caused by omitted variable bias, we use bank-level controls (for example, total assets, as larger banks may have more diverse boards). We also use country-level controls and regulatory agency fixed effects to account for unobserved country-specific and business model-specific characteristics that remain constant over time and might be correlated with misconduct. Reverse causality may arise as the direction of the causal relation is unclear ex-ante. Female directors can selfselect into a particular type of bank, either a more ethical or a less risky bank whose existing management is more aligned with their views. On the other hand, riskier banks may choose to appoint more women in a bid to reverse past problems (Ryan and Haslam 2005). In our context, the above issues would imply that current boardroom diversity could be determined by past misconduct. To account for these possible endogeneity issues, we use lagged values of the regressors and control for both the number and the dollar amount of previous misconduct fines.

We start by documenting differences in bank board composition for our sample of listed European banks. We find great heterogeneity in board size, tenure, age, and CEO characteristics. While we show an increase in female representation in bank boardrooms during our sample period, the industry remains heavily male-dominated and there are still bank boards with no female directors. Women in leadership positions including the CEO and chairperson roles are even less common. 
In our empirical analysis, we employ the negative binomial model to relate the frequency of misconduct fines to board gender diversity using the fraction of female directors as the key explanatory variable. We find that a greater presence of women on the board of directors is associated with fewer misconduct fines and the effect is economically significant. For the average change in the fraction of women in our sample, the number of fines decreases by a fraction of 0.27 , ceteris paribus. The estimated decrease in the frequency of banks' misconduct fines as a result of greater gender diversity is equivalent to saving approximately $\$ 7.48$ million per year. Additional analyses reveal that female directors tend to be more influential if they reach a critical mass, are supported by women in leadership roles (CEO and/or chairperson) and hold seats on boards of relatively smaller banks.

To test the predictions of the gender socialisation theory, that is, whether ethicality/risk aversion are the channels through which a greater female presence on banks' boards reduces incidences of misconduct, we distinguish among different types of fines according to the severity of the underlying offence. First, we distinguish between civil and criminal fines. ${ }^{5}$ We argue that criminal fines are more severe as they carry a higher professional and societal stigma; they are, on average, larger in amount and thus more harmful to the stakeholders of the bank. We find that a change in the proportion of female directors on the board is negatively (albeit weakly) associated with the incidence of criminal fines, thus providing some support to the gender socialisation theory. Next, we distinguish among different types of fines based on the underlying misconduct and proxy their severity by stock price reactions to the fine announcement. We define the following four categories of fines: (i) banking violations, which comprises misconduct fines banks incur in relation to their core banking business, including anti-money laundering; (ii) economic sanctions violations; (iii) market violations, and (iv) administrative violations, including tax violations and accounting deficiencies. Following a standard event study methodology, we find that share price reactions are more severe for economic sanctions compared to the other type of fines. This is consistent with the fact that economic sanctions tend to be

\footnotetext{
${ }^{5}$ Most US states recognise two types of offences - crimes and civil infractions. Crimes are a matter of criminal law and usually punishable by either time in jail or a fine, or both; civil infractions are generally punishable only by fines or administrative actions. A civil fine is a penalty for an offence not as serious as to be stipulated as a crime. Non-payment of a criminal fine can result in incarceration, whereas non-payment of a civil penalty cannot.
} 
related to exceptional events, attract more media attention, and carry a higher reputational risk. A breakdown of the regression analysis into the different types of fines reveals that an increase in the proportion of women on the board is associated with a lower frequency of economic sanction violations, thereby providing further support to the existence of an ethicality / risk aversion channel as a mechanism through which board gender diversity helps reducing misconduct.

Finally, we investigate whether it is diversity in general, and not specifically gender diversity, which reduces misconduct. The human capital theory posits that by widening the range of directors' skills, abilities, managerial approaches and preferences, board diversity is expected to yield benefits in terms of monitoring effectiveness. However, these potential benefits are not without costs, as conflicts may arise in more diverse boards, leading to more unpredictable decision making (Giannetti and Zhao, 2018). In line with the human capital theory, we expect other aspects of diversity, including age diversity, internationalisation, and employee representation, to have a misconduct-reducing impact. ${ }^{6}$ Our results show that while the preventive effect of female directors holds even in the presence of other dimensions of diversity, the impact of other types of board diversity on misconduct is not significant.

Our analysis is robust to using a Poisson model for the frequency of misconduct, a probit specification for the binary dependent variable of the incidence of fines, alternative proxies for gender diversity such as change in the fraction of women, and the use of country fixed effects instead of country controls. The impact of female directors is also analysed across different bank size groups and the findings suggest that they are most relevant for relatively smaller banks. Taken together, our findings provide support to the recent policy initiatives to support increased gender equality in traditionally male-dominated industries such as the banking sector.

Our paper contributes to the current literature and policy debate in several respects. First, our work is related to the literature that analyses the relationship between governance and risk in the banking

\footnotetext{
${ }^{6}$ Our choice of diversity indicators includes all the aspects suggested by recent regulatory guidelines (EBA, 2017), with the exception of educational and professional background due to data limitation. We use employee representation as a proxy of professional background and experience. The EBA (2017) document posits that employee representation in the boardroom could be seen as enhancing diversity, as it adds a different perspective and knowledge of the internal workings of companies.
} 
industry (Beltratti and Stulz, 2012; Ellul and Yerramilli, 2013; Nguyen et al., 2016). We contribute to the understanding of the determinants of bank conduct risk. Misconduct represents a cost to society, as banks subsequently incur severe financial and reputational penalties that in turn may hinder their ability to provide financial services. We also derive insights into the channels through which the preventive benefits of female participation materialise. In this respect, our results provide support to the role of women in strengthening the board's ability to address reputation and conduct risks. Our work also relates to the literature on board diversity and firm performance (Ahern and Dittmar, 2012; Liu et al., 2014; Giannetti and Zhao, 2018). The quality of a board's decision-making is likely to depend on the qualities and attributes of the directors, but also on the interaction between directors' characteristics (Cumming et al., 2015; Giannetti and Zhao, 2018). We contribute to this literature by disentangling the ethicality / risk aversion and the diversity hypotheses. More in general, we contribute to the debate on the role of women in leadership positions in the banking industry. Progress towards gender equality has been notoriously slow, despite the recent regulatory drive to increase diversity and to improve the participation of women and minorities in high profile roles. Recent evidence highlights that, globally, women hold less than 20 per cent of board seats of banks (Sahay and Cihak, 2018). Finally, our paper is related to the literature on the effect of sanctions and regulatory behaviour on bank risk (Ioannidou, 2005; Agarawal et al. 2014; Nguyen et al., 2016; Delis, 2017), the cost and availability of credit (Danisewicz et al., 2018; Deli et al., 2019).

The rest of the paper is organised as follows. Section 2 presents a review of the literature and hypotheses development. Section 3 discusses the data and univariate analysis. Section 4 presents the results of our main analysis and a set of robustness checks. Section 5 concludes.

\section{Literature and hypotheses development}

\subsection{Women on boards}

In recent years there have been several high-profile campaigns aiming to increase female representation on companies' boards of directors. Examples include the 2020 Women on Boards (2020WOB) in the US and the Hampton-Alexander Review in the UK. The report for the 2020WOB 
shows that the average number of board seats held by women in companies listed in the Russell 3000 Index has risen to 17.7 per cent in 2018, up from 16 per cent in 2016; however, half the companies in the index have one or no women on their boards. In particular, smaller companies are less diverse, with 13 per cent of female directors versus 25.3 per cent in the largest companies. ${ }^{7}$ The HamptonAlexander Review also reports an increase in the proportion of women on boards of FTSE100: it reached 30.2 per cent in 2018, up from 27.7 per cent in 2017. However, the number of women in leadership positions (CEO or chairperson) has scarcely changed in recent years and a large number of companies have only one woman on the board. ${ }^{8}$ This clearly shows that while some progress has been achieved, there is still a long way to attaining gender balance in corporate governance. The issue is even more relevant in the finance and banking industries, which are traditionally male-dominated.

Gender diversity is important not only from a societal point of view but also in terms of corporate performance. Boards of directors make decisions that impact all stakeholders, from employees to shareholders and customers. The relationship between board gender diversity and corporate performance is usually explained by agency theory (gender diversity improves the board monitoring function), by the human capital theory (gender diversity improves the board skills and expertise), and by behavioural-based theories, such as the gender socialisation theory (gender diversity improves the board monitoring role as women are more stakeholder-oriented).

With reference to agency theory, there is evidence that increased gender diversity in the boardroom can positively influence corporate outcomes in relation to key board functions, such as attendance, quality of discussions, and monitoring effectiveness including a better oversight of firm's disclosures and reports (Carter et al., 2003; Field and Keys, 2003; Terjesen et al. 2009; Adams and Ferreira, 2009; Gul et al., 2011). However, studies on the effects of board gender diversity on firm performance have produced mixed results (Adams and Ferreira, 2009; Adams and Funk, 2012; Ahern and Dittmar, 2012; Mateos de Cabo et al., 2012; Bennouri et al., 2018). Post and Byron (2015) provide an extensive review of the literature and conclude that the results are influenced by cultural norms and

\footnotetext{
${ }^{7}$ https://www.2020wob.com/sites/default/files/2020WOB_GDI_Report_2018_FINAL.pdf

${ }^{8} \mathrm{https} / /$ assets.publishing.service.gov.uk/government/uploads/system/uploads/attachment_data/file/764520/h ampton-alexander-review-report-nov18.pdf
} 
regulatory environments. More recently, Ye et al. (2019) document a positive and significant relationship between gender-diverse boards and the likelihood and the level of dividend pay-outs, which is consistent with the view that board gender diversity encourages effective corporate governance, thereby alleviating agency problems.

Based on the predictions on this strand of the literature, we derive our first testable hypothesis as follows:

Hypothesis 1 (Agency theory): Higher gender diversity of bank boards is associated with a lower number of misconduct fines.

\subsection{Gender, risk aversion, and ethicality}

There are many potential benefits to having a larger presence of female directors. The earlier literature finds that women are, on average, more risk-averse and less overconfident (Jianakoplos and Bernasek, 1998; Schubert et al., 1999; Croson and Gneezy, 2009, Price, 2012), although Sapienza et al. (2009) find that women who work in the financial industry tend to be less risk-averse compared to women in other industries. Women also bring enhanced corporate social responsibility and a more ethical perspective (Bryon and Post, 2016; McGuinnes et al., 2017). Richardson et al. (2016) find that more gender-diverse boards are associated with lower tax avoidance, whereas Garcia-Lara et al. (2017) document fewer incidences of account misreporting in firms with a higher percentage of female directors. Cumming et al. (2015) investigate the effect of board gender diversity on security fraud and find that it reduces both the frequency and the severity of fraud. Similarly, Liu (2018) investigates the relationship between board gender diversity and corporate environmental violations and finds that firms with more gender-diverse boards receive fewer environmental sanctions. Finally, female directors are found to be more stakeholder-oriented (Adams et al., 2011; Matsa and Miller, 2013) and less likely to pursue personal goals such as empire building through acquisitions (Levi et al., 2014). Based on the predictions of the gender socialisation theory, which posits that males and females are taught different appropriate behaviours, we expect female directors to be less inclined to commit misconduct. This might be a consequence of the fact that women are generally raised to be more 
caring, compassionate, and attentive to others' needs. In our context, this would translate in greater attention to stakeholders' needs, including depositors, investors, and employees (Ethicality channel).

On the other hand, gender might help explain differences in preferences and attitudes; for example, differences in sensitivity to social cues in determining appropriate behaviour (Croson and Gneezy, 2009; Alesina et al., 2013DellaVigna et al., 2013). One explanation for these behavioural differences is unequal discipline, that is, female employees responsible for missteps are subject to stricter penalties than their male counterparts. Egan et al. (2018) examine gender differences in misconduct punishment in the financial advisory industry and find evidence of a gender punishment gap. Against the background of a male-dominated industry, where male advisors engage in more severe misconduct both in terms of allegations and subsequent fines, the authors document that following an incident of misconduct, female advisers are 20 per cent more likely to lose their jobs and 30 per cent less likely to find new jobs relative to male advisers. We can argue gender roles and cultural norms may also mean that misconduct is more highly penalised for women and therefore less likely (Risk aversion channel).

However, untangling the mechanism through which the presence of women on boards of directors affects misconduct is challenging as differences in ethical sensitivity and risk aversion may overlap. To investigate the link between gender, ethical behaviour, and risk aversion, we consider the severity of the underlying misconduct. First, we distinguish between civil and criminal fines. The underlying assumption is that criminal fines are more severe as they carry a higher professional and societal stigma. In addition, they are, on average, larger and thus more harmful to the stakeholders of the bank. We argue that the impact of gender diversity should be stronger for criminal fines as female directors might exert greater monitoring and closer oversight of board decisions to avoid more severe offences. Second, we distinguish four broad categories of fines, according to the type of the underlying misconduct. Our first category, banking business, comprises misconduct fines banks incur in relation to their core banking business, including anti-money laundering. The next set includes fines for the breach of economic sanctions. Our third category relates to market violations, and our final category relates to administrative violations, including tax violations and accounting deficiencies. We proxy the 
severity of the different types of misconduct by stock price reactions to the fine announcement. We argue that if women are simply more ethical, then their misconduct-reducing effect should be similar for fines of different types. On the other hand, if risk aversion is also at play, we would expect the effect to be stronger for more severe fines as these are more harmful to the bank's shareholders and carry a higher reputational risk to board members.

We formulate our second hypothesis as follows:

Hypothesis 2 (Risk aversion / Ethicality channel): Higher gender diversity of bank boards is associated with a lower number of severe misconduct fines.

\subsection{Gender and diversity}

The potential benefits of having more female directors could be due to the general diversity that they bring to the board, so that the diversity in general is a potential mechanism of preventing bank misconduct. The key argument to support diversity, in line with the human capital theory, is that a more diverse management team tends to be more innovative and creative, more open to different ideas, and willing to consider a broader range of alternatives. The literature also provides some support for the human capital theory, as female directors are likely to have different views and therefore innovative ideas (Robinson and Dechant, 1997) and a broader set of skills in terms of educational and professional backgrounds, leading to better decision-making (Anderson et al., 2011). In addition, more diverse boards should be harder to manipulate. Arnaboldi et al. (2018) investigate whether board heterogeneity impacts on bank performance and find evidence to support the argument that diversity in board composition relates to different aspects in addition to gender, including age diversity (Carter et al, 2010; Li and Wahid, 2017); internationalisation (Adams and Ferreira, 2012; Oxelheim, 2013; Fahlenbrach et al., 2017), and employee representation (Adams and Ferreira, 2007). The literature on the impact of board diversity on firm performance yields mixed results. Giannetti and Zhao (2018) argue that board effectiveness is likely to depend not only on the characteristics of the directors but also on the interaction between the directors. While diverse groups might be better at problem-solving, there might also be more disagreements. Consistently, they find that diverse boards 
have more numerous and cited patents, but also have more frequent board meetings and make less predictable decisions, which increases firm performance volatility.

If it is diversity that matters, rather than the presence of female directors per se, we would expect other diversity features, as well as gender diversity, to be associated with a lower number of fines. This would be in line with the view that women are not different from men in leadership positions or at managing risks and that more diverse boards perform better simply because of the benefits of a multiplicity of views and skills (Nelson, 2014).

We test the diversity channel and formulate the following hypothesis:

Hypothesis 3 (Diversity channel): Higher diversity - not gender diversity per se - is associated with a lower number of fines.

\section{Data and methodology}

\subsection{Data and sample selection}

Our data set is compiled from several sources. We start by collecting data on corporate governance features of all publicly listed banks in the $28 \mathrm{EU}$ countries for the period 2007-18 from BoardEx. Where the BoardEx data are not complete, information on board members is sourced from Bloomberg and individual banks' annual reports. Next, we augment the BoardEx data with the banks' balance sheet and income statement data collected from Orbis Bank Focus and stock market data from Thomson Eikon. At this stage, we remove bank-years with missing board size or total assets data and exclude banks with less than three observations over the sample period. This yields a final sample of 83 publicly listed banks operating in 21 EU countries over the period 2007-18, which covers 72 per cent of the total assets of these countries' banking systems at the end of the sample period.

We then collect data on fines imposed on our sample banks by US regulatory agencies during the period 2009-2018 from Violation Tracker. ${ }^{9}$ We retrieve all sanction cases, and cross-check each sanction against the information available on the websites of the corresponding regulatory agencies

\footnotetext{
${ }^{9}$ Violation Tracker is a publicly available search engine on corporate misconduct. It covers cases initiated by more than 40 federal regulatory agencies and all divisions of the Justice Department since 2000.
} 
and their press releases, which yields a number of sanctions in addition to those reported on Violation Tracker. The sanctions data include the type of sanction, the fine amount, the fine date, a short description of the offense, an indication of whether the sanction is civil or criminal, and the sanctioning regulatory body. The sanctions contain, among others, charges for banking violations, anti-money laundering practices, economic sanction violations, market manipulations, investor and consumer protection violations, tax violations, accounting and data submission deficiencies, and employment discrimination. The sanctioning regulatory bodies include both the US bank regulators (that is, Federal Reserve, Office of the Comptroller of the Currency, Federal Deposit Insurance Corporation, and Consumer Financial Protection Bureau) and securities markets regulator (Securities and Exchange Commission); in addition, the US Department of Justice plays a key role in prosecuting misconduct related to criminal offences and anticompetitive behaviour of banks. We also collect fines issued by other regulatory agencies. ${ }^{10}$ Overall, we collect 146 sanctions resulting in both civil and criminal fines against EU listed banks during the period 2009-18. Finally, we augment the sample with country-level data collected from the World Economic Forum (2018) Global Gender Gap Report and International Monetary Fund.

\subsection{Variables}

To test Hypotheses 1 and 3, we calculate the dependent variable, N.Fine, as the number of misconduct fines imposed on a bank in a given year. In relation to Hypothesis 2, we employ a binary dependent variable, D.Fine_Criminal, which takes a value of one if a bank receives a criminal fine in a given year. We also use as dependent variable the number of misconduct fines imposed on a bank in a given year distinguishing between four main types of fines, that is, those related to: (i) banking business violations, N.Fine_Banking; (ii) economic sanction violations, N.Fine_Economic; (iii) market violations, N.Fine_Market; and (iv) administrative violations, N.Fine_Admin.

To test all our three hypotheses, we use Female Director \%, the proportion of female directors on the board in a given year, as our main board gender diversity variable (Cumming et al., 2015, Liu, 2018). In additional tests, we use a second board gender diversity variable, $\Delta$ Female Director $\%$, calculated

\footnotetext{
${ }^{10}$ See Appendix A for the full list of the sampled sanctions and the relevant sanctioning regulatory agencies.
} 
as the change in the proportion of female directors on the board in a given year. This variable captures the change in women representation in the boardroom regardless of the initial level, thereby reducing potential concerns that larger banks may have a higher proportion of female directors. Additionally, in order to investigate whether the effectiveness of female directors can be reinforced by the presence of women in other leadership positions, we use a dummy variable, Female Leader, which indicates a female chief executive officer (CEO) and/or chairperson or president.

In additional analyses, we include other dimensions of board diversity, besides female representation (EBA, 2017). We add director age diversity, Director Age Diversity, measured as the coefficient of variation for board directors' age which shows the dispersion of age within the board. We also include board internationalisation, Foreign Director \%, measured as the proportion of foreign directors on the board. We add employee representation, Employee Representative \%, measured as the proportion of employee representatives on the board.

We employ a series of control variables, including board, bank, and country characteristics. Board size, Ln(Board Size), is measured as the natural logarithm of the number of directors on the board. Director tenure, Ln(Director Tenure), is the natural logarithm of the average tenure length of directors on the board. Director age, Ln(Director Age), is the mean age of board directors in logarithm form. We also include CEO characteristics: CEO tenure, $\operatorname{Ln}(C E O$ Tenure), is the natural logarithm of the CEO's tenure length; CEO age, $\operatorname{Ln}(C E O$ Age $)$, is the natural logarithm of the CEO's age; CEO turnover, CEO Turnover, is a dummy variable equal to one in the year a new CEO is appointed.

Turning to bank-specific controls, we include bank size, Size, measured as the natural logarithm of total assets. Larger banks tend to be more frequently fined. Moreover, large banks tend to be complex, which can potentially impact the effectiveness of the board in preventing misconduct. Return on equity, $R O E$, is included to account for the profitability of a bank, whereas risk is captured using the volatility of stock returns, Stock Return Volatility, measured as the annualised volatility of daily stock market returns. We use the two latter variables as proxies for the financial health of a bank, to account for the existing evidence that firms in financial distress are more likely to commit fraud (Beasley, 
1996; Cumming et al., 2015). We also include Tobin's Q, Ln(Tobin's Q), to control for bank charter value (Liu, 2018). All bank-specific controls are winsorised at the 5 percent level.

For the country-specific controls, we include the country's gender index rank, Gender Index Rank, which is based on the gender gap index score published by the World Economic Forum (2018) and captures the relative gaps between women and men in a country across four areas: health, education, economy, and politics. We also control for the macroeconomic conditions by including the GDP growth rate, GDP Growth. Finally, we include a dummy variable, G10, which takes the value of one for the G10 countries, that is, most developed economies.

\subsection{Model specification}

To determine whether gender diversity of the board is associated with bank misconduct, we employ the following model in a panel setup for bank-year it in country $j$ :

$$
\begin{aligned}
& \text { Misconduct }_{i t, j}=\beta_{0}+\beta_{1} \text { Gender diversity }_{i, t-1}+\beta_{2} \text { Gender Index Rank } \\
& +\beta_{3} \text { Female Leader }_{i, t-1}+\beta_{4} \text { N. Fine }_{i, t-1}+\beta_{5} \text { Ln }(\text { Fine })_{i, t-1}+\beta_{6} \operatorname{Ln}(\text { Board Size })_{i, t-1} \\
& +\beta_{7} \operatorname{Ln}_{\text {(Director Tenure })_{i, t-1}}+\beta_{8} \operatorname{Ln}(\text { Director Age })_{i, t-1}+\beta_{9} \operatorname{Ln}(\text { CEO Tenure })_{i, t-1} \\
& +\beta_{10} \operatorname{Ln}(\text { CEO Age })_{i, t-1}+\beta_{11} \text { CEO Turnover } \text { Tit-1 }_{12}+\beta_{12} \text { Size }_{i, t-1}+\beta_{13} \text { ROE } E_{i, t-1} \\
& +\beta_{14} \text { Stock Return Volatility }_{i, t-1}+\beta_{15} \text { Ln }_{\text {Tobin's } Q)_{i, t-1}}+\beta_{16} \text { GDPGrowth }_{j, t-1} \\
& +\beta_{17} G 10_{j}+\sum Y_{\text {ear }}^{i}+\sum \text { Agency }_{t}^{i}+\varepsilon_{i t, j}
\end{aligned}
$$

We include the number and dollar amount of fines received by bank $i$ in the year $t-1$ in the specification, to control for the impact of previous sanctions on the bank's misconduct and the expected additional effort of regulatory authorities with recently $(t-1)$ sanctioned banks. Year fixed effects are included to control for changes in the macroeconomic environment over time. We also include agency fixed effects to control for the different bank activities the sanctioning agencies supervise. The correlation matrix for the variables used in the regression analysis is reported in Appendix C. 
To test our hypotheses, we deploy a negative binomial count model as the appropriate approach for modelling the number of fines per year in the presence of overdispersion in the dependent variable. To test Hypothesis 2, we also use a probit model for the binary dependent variable representing the incidence of criminal fines. We conduct robustness checks using the binary dependent variable (occurrence of fines) in a probit context and a Poisson model instead of a negative binomial that disregards overdispersion in the data.

\subsection{Endogeneity}

As in many corporate governance analyses, endogeneity concerns are an issue when modelling the relationship between female representation on the board and bank misconduct. Endogeneity could be the result of reverse causality due to the potentially non-random selection of women on the board. That is, the possibility for instance that women aim at becoming directors of banks that are less inclined to misconduct; or that they decide to leave the board as they acquire information about misconduct becoming more likely. Alternatively, troubled banks may choose to appoint more women in a bid to reverse past problems in a phenomenon known as cliff glass (Ryan and Haslam, 2005). On the other hand, banks that are more inclined to transgressions might decide to avoid having diverse boards. Omitted variable bias could be another source of endogeneity due to the challenges of determining all the factors driving bank misconduct.

To address the issue of reverse causality that may bias our results, we run all the regressions using lagged variables for both board characteristics and bank-level controls (Dittmann et al., 2010; Liu, 2018). Controlling for previous fines also helps to alleviate the concern that our results are driven by women joining boards of banks that received fewer fines. Changes in corporate governance, such as CEO turnover and board tenure, that could discourage women to join the board for similar reasons is also a factor we control for. One additional concern could be related to the lack of specific information on the actual date the misconduct occurs. We consider realised misconduct, that is, the cost that the bank incurred as a result of the breach of rules and regulations. In this context, the types of misconduct that we consider are relevant to the current board as they are harmful both financially and from a reputational point of view. In addition, the current board of directors is liable for past 
misconduct and in charge of negotiating with regulators, which ultimately defines the outcome of sanctions.

We address endogeneity caused by the omitted variable bias by using bank-specific controls (for example, size as larger or more profitable banks may have more gender-diverse boards) and by employing country-level controls as well as regulatory-agency effects to account for unobserved country-specific characteristics that are time-invariant and may be correlated with the level of gender diversity (that is, a country's corporate culture) and for a bank's business model.

More in general, in our set-up, the issue of the women reacting to future misconduct is mitigated by our exogenous identification of bank misconduct based on US regulators. During the post-crisis period, the activism of the US regulators on European banks was exceptional, both in reach and severity of fines. To some extent, only in more recent years, the role of the US regulators as a global regulator has been established. This increased intensity in their supervisory effort on European banks also mitigates the concerns of undetected misconduct.

\section{Empirical results}

\subsection{Descriptive statistics}

Table 1, Panel A, reports the descriptive statistics for the sample used in the regression analysis. Female directors are present in $86.8 \%$ of the bank-year observations. The sample banks average 16 directors on their boards, of which $16.4 \%$ are women, with a maximum of $60 \%$ and a minimum of $0 \%$. Only $4.7 \%$ of the bank-year observations have a female CEO, whereas $23.2 \%$ have a female chairperson and $25.5 \%$ have women in leadership either through the CEO and/or chairperson roles.

\section{[Insert Table 1 about here]}

Panel B of Table 1 reports the summary statistics for the fines issued against the sample banks. Around $7 \%$ of the bank-year observations have received misconduct fines. Of those, over one third are related to criminal sanctions ( $2.4 \%$ of the bank-year observations). On average, sample banks are 
levied 0.169 misconduct fines per year, with a maximum of 8 and a minimum of $0 .{ }^{11}$ The most frequent type of fines are the ones related to market violations; on average, banks experience 0.057 market lawsuits per year.

Table 2 reports the evolution of female participation in the governance of the sample banks. Gender diversity increased over the sample period (and consistently so from 2010), with female directors being present in more boards and in a greater proportion. In particular, the number of banks with female directors increased from $80 \%$ to $96.1 \%$ of the sample between 2007 and 2017. Female representation on the board gradually increased from an average of $10.4 \%$ in 2007 to $26.1 \%$ in 2017 . The presence of female leaders also shows an upward trend during the sample period. Female CEOs witnessed the greatest increase from only $1.5 \%$ bank-year observations with female CEOs in 2007 to $7.9 \%$ in 2017 , whereas female chairpersons increased from an average of $16.9 \%$ to $36.8 \%$; the presence of female leaders in general increased from an average of $18.5 \%$ to $38.2 \%$ of bank-year observations between 2007 and 2017. Nevertheless, despite the tendency of banks to improve board gender diversity, their boardrooms remained male-dominated over the sample period.

[Insert Table 2 about here]

Table 3 reports detailed summary statistics for misconduct fines of the sample banks by year. The total number of fines issued over the sample period is 146 , with an average dollar amount per fine of $\$ 364.6 \mathrm{~m}$ and a maximum of $\$ 9 \mathrm{bn} .{ }^{12}$ Panels B and C of Table 3 report for each year in the sample the average aggregate fine amount received by each bank and the total amount fined across banks, respectively. The mean dollar amount fined in a bank-year is $\$ 872.7 \mathrm{~m}$ and the total dollar amount fined across the sample is $\$ 53.2 \mathrm{bn}$. The incidence of fines increased over the sample period, especially post-2012, peaking at 36 fines in 2015 . The major share of fines both in incidence and dollar amount is related to market violations, with 49 fines over the sample period averaging $\$ 1.1 \mathrm{bn}$ per fine and amounting close to $\$ 30.6 \mathrm{bn}$ in total. Fines related to economic sanctions, albeit not as frequent (25 fines), hold the second largest share after market lawsuits accounting for over \$14.2bn in

\footnotetext{
${ }^{11}$ The maximum number of misconduct fines is observed for Société Générale in 2018.

12 The maximum amount (\$9bn) was levied against BNP Paribas in 2015 , followed by $\$ 7.9 \mathrm{bn}$ against Deutsche Bank in 2017, and \$5.6bn against the Royal Bank of Scotland in 2017.
} 
total, with an average fine value of $\$ 791.1 \mathrm{~m}$. Fines related to banking business violations are relatively frequent (41 fines), but with a substantially smaller average amount of $\$ 248.9 \mathrm{~m}$ and a total amount of $\$ 6.5 \mathrm{bn}$. Fines related to administrative violations are the smallest in average amount (\$76m) and numbers (31 fines), amounting to $\$ 1.9 \mathrm{bn}$. Overall, market manipulations and economic sanction violations are the most heavily penalised.

[Insert Table 3 about here]

\subsection{Univariate analysis}

Table 4 reports the results of the univariate analysis where the sample banks are grouped based on board gender diversity. A bank is assigned to the high or low gender diversity sub-sample if the proportion of female directors in year $t-1$ is above or below the sample median, respectively. The data show that banks categorised into the high gender diversity group experience a higher number of misconduct fines than banks in the low gender diversity group, however this does not take into account other board and bank-level characteristics that could potentially drive the difference. Banks with more gender-diverse boards tend to be larger and have lower market risk and lower charter value. They are more likely to also have women in leadership positions including both the CEO and chairperson roles and a greater employee representation on the board.

[Insert Table 4 about here]

\subsection{Regression analysis}

\subsubsection{Do female directors reduce misconduct?}

Table 5 reports the results of our negative binomial regression model for Hypothesis 1 . Drawing on agency theory, we hypothesise a negative relationship between board gender diversity and bank misconduct. The negative binomial regression models estimate the relationship between our proxy of board gender diversity and the number of fines received by bank $i$ in year $t$, employing a set of governance or board-level controls, bank- and country-level controls, and year and regulatory agency

fixed effects. Standard errors are clustered at the country level to accommodate country-wise contemporaneous correlation caused by economic conditions and regulatory standards. 
Models (1)-(3) focus on the effect of female directors on bank misconduct behaviour and employ as the key test variable the fraction of women on the board (Female Director \%). To capture bank-level autocorrelation caused by the regulators' imposing greater scrutiny towards banks that have a misconduct record, all models include the misconduct fines, number and dollar amount, received by a bank in the previous year as additional regressors. In Model (2), we add a time-invariant country-level control to capture the progress towards gender equality in the country where the bank is headquartered (Gender Index Rank), and in Model (3) we control for the effect of the presence of women in leadership positions within the governance of the bank including the CEO and/or chairperson or president roles (Female Leader). These models constitute our baseline specifications.

\section{[Insert Table 5 about here]}

The coefficient of our board gender diversity variable is negative and significant in all models. This indicates that female representation on the board is negatively associated with the frequency of misconduct fines. The coefficients in a negative binomial model can be directly interpreted as the change in the log differential of expected counts per unit change in the regressor or converted into the incidence rate ratio (IRR) which represents the change in the rate of incidence of fines. We convert the reported coefficients into the IRR using the exponential of the estimated coefficient multiplied by the change in the independent variable $\left(\mathrm{e}^{\beta \Delta x}\right)$ to obtain the ratio of the rate of fines per year, N.Fines ${ }_{1} /$ N.Fines $s_{0}$, generated by the given change in our measure of gender diversity $\Delta x=x_{1}-x_{0}$. Thus, our parameter estimates suggest that a one-unit increase in the proportion of women on the board decreases the frequency of fines by a fraction of 0.27 , ceteris paribus. For the average change in the fraction of women in our sample (0.016) the number of fines will decrease by a fraction equal to $(0.27)^{0.016}=0.98$. Given that the average fine amount in our sample is $\$ 364.6 \mathrm{~m}$, about $0.12 \%$ of banks' average total assets, the estimated decrease in the frequency of banks' misconduct incidences as a result of greater gender diversity on the board is equivalent to saving approximately $\$ 7.48 \mathrm{~m}$ per year. The merit of female directors remains even after controlling for the level of gender equality in the country where the bank is headquartered and the presence of women in leadership positions within the bank's governance. 
The coefficient for the number of previously received misconduct fines is positive and significant, suggesting that misconduct episodes tend to be recurrent. However, the coefficient for the dollar amount of misconduct fines in the previous year has a negative and significant sign, suggesting that a more severe regulatory penalty can have a beneficial effect in decreasing the incidence of future misconduct (disciplining effect). Both the gender equality index and the presence of women in leadership positions show the expected negative signs but are not significant.

As to the other controls, we find a positive and significant sign for bank size. This is not surprising, as larger banks with more cross-border activities are more frequently in the spotlight of regulators and thus more frequently fined. We also find a positive and significant coefficient for our proxy of bank risk (Stock Return Volatility), confirming that riskier banks are more likely to have lower conduct standards. Among our governance controls, we find that the length of the CEO tenure is positively associated with the frequency of misconduct fines. This is in line with the CEO entrenchment literature, suggesting that longer tenure might result in the CEO becoming more powerful and more likely to take risks (Bebchuk and Kamar, 2010). In addition, Hermalin and Weisbach (1998) show that monitoring declines as CEO tenure increases, possibly suggesting that the board becomes more entrenched and thus slower in detecting potential misconduct.

\section{Critical mass}

To explore the drivers of the effect of board gender diversity on bank misconduct we consider several tests. Our first test draws upon the critical mass theory, which posits that as female directors are outnumbered by their male counterparts, their number would have to exceed a certain minority threshold for them to be able to have any material impact on corporate outcomes such as monitoring, performance, and prevention of misconduct. There is consensus in the empirical literature that three or more directors form a critical mass and, in such instances, female directors would be more effective in voicing their opinion and influencing corporate decision-making (Liu et al, 2014; Liu, 2018). Thus, we run our baseline specifications in Eq. (1) using as a proxy of gender diversity an indicator variable (Critical Mass) for a minimum of three female directors. The results are reported in Table 6, Models 
(1)-(3). All models bear out a more significant role of gender diversity in curbing misconduct when the number of female directors reaches a critical mass.

\section{[Insert Table 6 about here]}

In Models (4)-(5) we test whether the role of female directors, either in the form of critical mass or simply proportional presence, becomes more effective in reducing bank misconduct if supported by a female CEO, president, or chairperson (Female Leader interaction terms). The incremental effect of women in leadership positions is statistically significant only when there is no critical mass. This is evident by the fact that the impact of the proportion of female directors is only significant when there is also a woman in a leadership role. This additional effect disappears if there is female critical mass.

\section{Bank size effect}

The univariate analysis revealed that larger banks are more gender-diverse, but also more frequently fined. To control for the fact that larger banks receive more fines we introduce size effects in the baseline model by categorising the banks into quartiles based on total value of assets. We then assess the differential impact of gender diversity on misconduct for the large (top quartile) banks versus other banks by incorporating interaction terms between the fraction of female directors and the size dummy variables (Size Qi). The results of this test are presented in Table 7.

\section{[Insert Table 7 about here]}

We find that large banks (first and second quartile), as expected, receive on average a higher number of fines but there is no evidence of an impact of gender diversity on misconduct for the banks of the top size quartile - the interaction term capturing the fraction of female directors in $Q_{l}$ has the expected negative sign, but is statistically insignificant. Instead, we find a misconduct-reducing effect for the rest of the sampled banks as indicated by the negative and strongly significant interaction coefficient in $Q_{234}$. This result reveals that the aggregate findings in Table 5 exhibit bank size heterogeneity that when accounted for leads to even stronger support for Hypothesis 1. 


\section{Change in proportion of female directors}

To complete our evidence in support of Hypothesis 1, we run the baseline specifications using as key variable the change in the fraction of female directors on the board between year $t$ and year $t-1$ ( $\Delta$ Female Director \%). This proxy has two advantages. While the previous specifications in Table 5 tested for the level of women participation, this proxy captures the change in the degree of women participation regardless of the initial level and therefore is less influenced by board size, which is in turn related to bank size. The results of this test are presented in Table 8.

\section{[Insert Table 8 about here]}

We find that with a one-unit increase in the change in the representation of women on the board, the number of fines decreases by a factor of $4-5 \%$, ceteris paribus. Overall, the beneficial impact of female board directors on bank conduct as predicted in Hypothesis 1 is confirmed.

\subsubsection{Gender diversity and ethicality / risk aversion}

In this section we attempt to shed light on the channels through which women presence on the board can reduce bank misconduct. One of the challenges is the difficulty to disentangle the ethicality and risk aversion channels. The gender socialisation theory argues that women's influence derives from their ability to foster more ethical decision-making (Cumming et al., 2015; Bryon and Post, 2016; McGuinnes et al., 2017; Liu, 2018). A higher female participation should therefore increase the board's attitude towards more ethical issues, such as avoiding involvement in activities that could potentially undermine trust and confidence in the bank, and thus lead to a reduction in misconduct. On the other hand, gender might help explain differences in preferences and behaviour (Croson and Gneezy, 2009; DellaVigna et al., 2013) and risk attitude driven by the existence of a gender punishment gap (Egan et al., 2018). In our context, female directors' role in improving conduct could be driven by either ethical values or risk aversion.

To this end, we explore whether the mechanism through which gender diversity relates to bank misconduct can be identified in the link between female directors and the occurrence of severe offences. First, we distinguish between civil and criminal fines. The underlying assumption is that 
criminal fines reflect more serious types of misconduct that substantially deviate from ethical codes of conduct. Indeed, criminal fines are rare (amounting to less than 3 per cent of sample year observations) but also often carry a custodial sentence and a lifetime ban from working in the industry.

The results of this test are reported in Table 9. All models are estimated using a Probit specification for the occurrence of criminal fines and use the same set of controls as the baseline regressions presented in Table 5. Our dependent variable is a dummy variable (D.Fine_Criminal) which is equal to one if a bank receives a fine imposed by a court for criminal offences and zero otherwise.

\section{[Insert Table 9 about here]}

In Model (1) the coefficient on gender diversity suggests that the bigger the increase in the proportion of women on the board the lower the probability of criminal misconduct. However, the coefficient is weakly significant, Model (1), or not statistically significant, Models (2)-(3), providing only weak support for the ethicality channel.

In Model (4) we augment the specification with an interaction term between the fraction of female directors on the board and the level of gender equality in the country where the bank is headquartered. This additional test aims to investigate whether the association of female directors with bank criminal misconduct depends on the country institutional culture, that is, more or less supportive of gender equality. The coefficient for the interaction term is negative and significant, while the coefficient for female directors is still negative but loses significance. We interpret this result as evidence that the role of women in supporting a more ethical behaviour of the board is closely intertwined with the recognition of their role in the society in which they operate. In other words, the ethical impact of female directors is only effective in countries with a higher level of gender equality.

In Model (5) we augment the specification with an interaction term between the fraction of female directors on the board and the presence of women in leadership positions within bank governance. This test further examines whether the ethical role of gender diversity is more prominent in banks with women in leadership positions (ethical behaviour encouraged at the top). The result suggests that the 
ethical role of female directors on the board is not enhanced by women representation in leadership roles within the governance of the bank.

In an attempt to distinguish the ethicality from the risk aversion channel, we posit that if women are simply more ethical, then their misconduct-reducing effect should be similar for fines of different type. On the other hand, if risk aversion is also at play, we would expect the effect to be stronger for fines associated with greater reputational risk.

Following Cumming et al. (2015), we conjecture that the severity of fines and, in turn, their reputational effect is represented by the extent of stock market reaction triggered by the fine. In an event study set-up, we measure the effect of fines on share prices based on the abnormal reaction of the bank suffering the fine computed as the deviation of its stock return from its expected value. The latter is estimated using the constant return model computed over the whole sample period. ${ }^{13}$ The Cumulative Abnormal Return (CAR) associated with misconduct fines is then regressed on four dummy variables indicating the type of fine. ${ }^{14}$ The estimated regression coefficients represent the Cumulative Average Abnormal Return (CAAR) and its significance is assessed using the crosssectional variation across the events through the t-statistic. The results of the event study are reported in Table 10.

[Insert Table 10 about here]

The findings are supportive of the view that economic sanction violations are more severe and carry higher reputational risk than the other types of fines. Economic sanction violations prompt significantly negative stock market returns in contrast to banking business, market, and administrative violations. The effect becomes apparent for larger event windows with a significant CAAR of $-5.1 \%$ for the $[0,6]$ day event window, $-7.6 \%$ for 6 to 9 days and $-6.0 \%$ for 10 days after the event. The

\footnotetext{
${ }^{13}$ The gains from employing the market model as opposed to the constant return model for the estimation of abnormal return in event studies are linked to reducing the variance of the abnormal return. However, Brown and Warner (1984) find that for random samples and short time periods, the market model is not systematically better at identifying the presence of abnormal returns than models that do not incorporate market-wide factors and firm-specific risk.

${ }^{14}$ Appendix A provides a description of the types of fine in each category.
} 
abnormal returns associated with the other three types of fines are insignificant across all event windows.

The results are robust to the choice of expected return used as input for deriving the abnormal returns as well as alternative regression specifications. Using the mean return over the 252 and 504 days before the announcement to estimate the expected return as well as including year and country fixed effects in the CAR regressions we obtain virtually identical results, which are available upon request.

We now turn to examine whether the role of board gender diversity in reducing the number of fines varies depending on the severity of fine. Building on our event study finding of a more aggravate market response for economic fines we run our baseline specification in Eq. (1) linking gender diversity and frequency of fines for each of the four fine sub-samples.

The results of this test are reported in Table 11.

[Insert Table 11 about here]

We find a negative and significant coefficient for our proxy of board gender diversity (Female Director \%) only in relation to economic sanction violations, which as indicated by our event study are considered to be the most severe type of fines. This provides further support to the view that gender has a significant effect on the attitudes of managers towards business ethics but also risktaking. Economic sanctions are the result of complex and sometimes inconsistent global regimes, coupled with the increasing rigor in enforcements by US regulators. In this context, female directors can be influential in helping banks navigate the regulatory landscape and decrease the incidences of economic sanction violations, which are considered by the market as the ones that incur the highest reputational costs.

Overall, the results in this sub-section support the risk aversion channel of Hypothesis 2 as the mechanism through which gender diversity improves bank culture and reduces conduct risk. 


\subsubsection{Gender diversity over other types of diversity}

Our Hypothesis 3 postulates that the impact of female directors might be less important in boards that are more diverse overall. We test this hypothesis by augmenting our baseline models with three other measures of board diversity, namely, age diversity captured by the coefficient of variation of the board directors' age (Director Age Diversity), internationalisation proxied by the fraction of foreign directors (Foreign Director \%), and employee representation measured as the fraction of employees (Employee Representative \%) on the board (Arnaboldi et al., 2018). The results of this test are reported in Table 12.

[Insert Table 12 about here]

The coefficient for gender diversity is negative and significant in all models. Interestingly, none of the other diversity characteristics seems to have an impact on the frequency of misconduct. These findings suggest that female directors exert a strongly significant negative effect on bank misconduct even in the presence of other aspects of board diversity. Overall, the results vindicate rejection of Hypothesis 3 and support the view that the reduction in bank misconduct can be attributed to the role of female directors rather than a general effect of a more diverse board.

\subsubsection{Robustness tests}

We run the following additional tests. First, we run our baseline regressions using a Poisson model for the rate of fine occurrence, as it is a simpler model for count variables but disregards the overdispersion exhibited by our count data with a large number of zeros. The results remain unchanged and are available upon request. The likelihood ratio test for the significance of the overdispersion parameter also shows that the two models are statistically identical.

Second, we run our baseline specifications including country fixed effects on a sub-sample of countries with at least three banks. The results of this test are presented in Table 13. We find negative and significant coefficients for our proxies of board gender diversity and evidence of bank size heterogeneity in the impact of female directors, both consistent with the results obtained using 
country-level controls. Therefore, we can exclude the possibility that our results are driven by unobserved fundamental differences in the social, economic, and regulatory contexts across countries.

[Insert Table 13 about here]

In a third test, we address the literature on the glass cliff effect which posits that women are often appointed into leadership positions that are associated with increased risk of failure and test whether our results are driven by female directors joining boards of banks that are already experiencing distress (Ryan and Haslam, 2005; Haslam and Ryan, 2008; Liu, 2018). To do so, we exclude the cases of women joining the board during "troubled" times by dropping observations where the change in stock price volatility in the previous year is equal to or higher than the $75^{\text {th }}$ percentile of the sample. The results of this test are reported in Table 14. The coefficients for our proxies of gender diversity remain negative and significant across all models after controlling for the potential glass cliff effect, which supports the validity of our Hypothesis 1.

[Insert Table 14 about here]

Finally, we test the robustness of our baseline results to the model specification using a pooled Probit model for the probability of being sanctioned. The dependent variable is a dummy equal to one when a bank is fined and zero otherwise. The results of this test are reported in Table 15. The findings for our main proxy of gender diversity hold; the size differences in the effect of female directors on bank misconduct are also evident in this specification.

[Insert Table 15 about here]

\section{Conclusions}

This study examines the relationship between board gender diversity and bank misconduct as captured by the civil and criminal fines imposed by US regulators on European banks. Bank misconduct has significant implications not only for individual financial institutions, as large regulatory fines can harm their soundness but also for society as misconduct events reduce the trust in the financial system. Therefore, it is important to understand the role of board gender diversity in reducing bank 
misconduct, as its implications are systemic in nature and contribute to strengthening financial stability.

Post-crisis, US regulators have issued a record number of fines to foreign financial institutions. This offers a unique set-up for our analysis that mitigates regulatory capture bias. We hand-collect and analyse misconduct fines issued to European listed banks by all US regulatory agencies, both relating to criminal sanctions and civil infringements. We find that a larger presence of women on the board of directors is associated with fewer misconduct fines. The effect is economically significant: the estimated decrease in the frequency of banks' misconduct fines as a result of greater gender diversity on the board is equivalent to a saving of $\$ 7.48$ million per year. These results seem to provide support to the view that increased gender diversity helps reducing conduct risk, that is, it helps fostering a better corporate culture.

To understand the mechanisms through which the presence of women affects bank misconduct, we test the ethicality / risk aversion channel versus the diversity channel. We find evidence to support the ethicality channel, as indicated by the lower number of criminal fines, conditional on the bank being based in a country with a lower gender gap. We also find support for the risk aversion view, as gender diversity is associated with reducing severe types of misconduct such as economic sanction violations, currently one of the biggest sanction-related challenges for US and European banks. To test the diversity view, we consider other aspects of board diversity, including age diversity, the presence of foreign directors and employee representatives. We find no evidence to support that it is board diversity, rather than the presence of women, that is associated with decreased bank misconduct. Our results therefore suggest that women bring a special set of skills to corporate boards, in line with the gender socialisation theory interpretation.

Interestingly, the impact of women representation on bank misconduct is not present for the largest banks. While current reforms often target the inclusion of more female directors in larger banks, our results point towards a beneficial effect of board gender diversity also for medium-sized and smaller banks. Such banks may not have the same relevance for financial stability as larger banks, but their role in maintaining trust and confidence in the financial system should be taken into account. 
Additional evidence points to a recidivism of bank misconduct and the strong deterrent represented by larger monetary penalties.

One limitation of this study is that it does not directly investigate whether the regulatory fines as a consequence of misconduct events trigger changes in the governance of the bank, or prompt the bank's senior management to consider including more women on the board in order to increase the perceived ethicality of the board to stakeholders and regulators. Additional analyses could also explore whether the relationship between board gender diversity and bank misconduct has positively benefited from the recent corporate governance reforms that many countries adopted post-crisis. This would provide evidence to support the adoption of gender quotas not only for improving diversity in boardrooms and strengthening governance, but also for promoting bank behaviour to restore trust in the financial industry. 
Table 1: Summary statistics.

\begin{tabular}{lllllll}
\hline Variable & $\mathrm{N}$ & Mean & Median & Std. dev. & Minimum & Maximum \\
\hline Panel A: Corporate governance & & & & & & \\
& & & & & & \\
Female Director & 789 & 0.868 & 1.000 & 0.339 & 0.000 & 1.000 \\
Female Director \% & 789 & 0.164 & 0.148 & 0.121 & 0.000 & 0.600 \\
$\Delta$ Female Director \% & 693 & 0.016 & 0.000 & 0.058 & -0.250 & 0.222 \\
Female CEO & 789 & 0.047 & 0.000 & 0.212 & 0.000 & 1.000 \\
Female Chair & 789 & 0.232 & 0.000 & 0.422 & 0.000 & 1.000 \\
Female Leader & 789 & 0.255 & 0.000 & 0.436 & 0.000 & 1.000 \\
Board Size & 789 & 16.129 & 15.000 & 5.916 & 4.000 & 41.000 \\
Director Tenure & 789 & 6.203 & 5.900 & 2.781 & 0.100 & 16.671 \\
Director Age & 789 & 58.325 & 58.588 & 4.602 & 35.800 & 70.385 \\
CEO Tenure & 789 & 5.857 & 4.000 & 5.110 & 1.000 & 28.000 \\
CEO Age & 789 & 56.103 & 56.000 & 7.278 & 33.000 & 79.000 \\
CEO Turnover & 789 & 0.147 & 0.000 & 0.354 & 0.000 & 1.000 \\
Director Age Diversity & 789 & 0.145 & 0.142 & 0.047 & 0.013 & 0.905 \\
Foreign Director \% & 789 & 0.197 & 0.182 & 0.204 & 0.000 & 1.000 \\
Employee Representative \% & 789 & 0.074 & 0.000 & 0.127 & 0.000 & 0.600 \\
& & & & & & \\
\hline
\end{tabular}

Panel B: Misconduct fines

\begin{tabular}{lllllll}
\hline & & & & & \\
D.Fine & 863 & 0.071 & 0.000 & 0.256 & 0.000 & 1.000 \\
N.Fine & 863 & 0.169 & 0.000 & 0.77 & 0.000 & 8.000 \\
N.Fine_Banking & 863 & 0.048 & 0.000 & 0.299 & 0.000 & 3.000 \\
N.Fine_Economic & 863 & 0.029 & 0.000 & 0.221 & 0.000 & 3.000 \\
N.Fine_Market & 863 & 0.057 & 0.000 & 0.341 & 0.000 & 4.000 \\
N.Fine_Admin & 863 & 0.036 & 0.000 & 0.220 & 0.000 & 2.000 \\
Fine (m) & 863 & 61.686 & 0.000 & 520.126 & 0.000 & 9033.557 \\
D.Fine_Criminal & 863 & 0.024 & 0.000 & 0.154 & 0.000 & 1.000 \\
& & & & & &
\end{tabular}

Panel C: Bank- and country-level controls

\begin{tabular}{lllllll}
\hline & & & & & & \\
Total Assets (bn) & 789 & 306.766 & 76.275 & 473.087 & 3.263 & 1641.308 \\
ROE & 789 & 0.064 & 0.076 & 0.106 & -0.210 & 0.248 \\
Stock Return Volatility & 787 & 0.384 & 0.338 & 0.183 & 0.140 & 0.811 \\
Tobin's Q & 785 & 2.278 & 1.004 & 3.333 & 0.927 & 13.612 \\
GDP Growth & 789 & 0.992 & 1.400 & 2.844 & -9.100 & 25.000 \\
Gender Index Score & 789 & 0.745 & 0.738 & 0.039 & 0.674 & 0.822
\end{tabular}

The table reports the summary statistics for the sampled banks. Bank-level control variables are winsorised at the 5 percent level. Definitions of the variables are provided in Appendix B. 
Table 2: Female representation in bank governance.

\begin{tabular}{llllll}
\hline & Female Director & Female Director \% & Female CEO & Female Chair & Female Leader \\
\cline { 2 - 6 } 2007 & 0.800 & 0.104 & 0.015 & & \\
2008 & 0.806 & 0.113 & 0.015 & 0.169 & 0.185 \\
2009 & 0.716 & 0.103 & 0.015 & 0.209 & 0.224 \\
2010 & 0.750 & 0.101 & 0.044 & 0.176 & 0.224 \\
2011 & 0.824 & 0.111 & 0.044 & 0.235 & 0.206 \\
2012 & 0.859 & 0.132 & 0.042 & 0.197 & 0.265 \\
2013 & 0.938 & 0.165 & 0.037 & 0.188 & 0.225 \\
2014 & 0.944 & 0.204 & 0.070 & 0.211 & 0.239 \\
2015 & 0.949 & 0.226 & 0.064 & 0.256 & 0.282 \\
2016 & 0.949 & 0.250 & 0.077 & 0.308 & 0.333 \\
2017 & 0.961 & 0.261 & 0.079 & 0.368 & 0.382 \\
\end{tabular}

The table reports the statistics on gender diversity in bank governance over the sample period. The mean value is reported for: (i) female director dummy variable, (ii) fraction of female directors, (iii) female CEO dummy variable, (iv) female chairperson / president dummy variable, and (v) female leader dummy variable. Definitions of the variables are provided in Appendix B. 
Table 3: Misconduct fines - Time trend by sanction type.

Panel A: Number of fines

\begin{tabular}{llllll}
\hline & N.Fine & N.Fine_Banking & N.Fine_Economic & N.Fine_Market & N.Fine_Admin \\
\cline { 2 - 6 } 2009 & 6 & 1 & 2 & 0 & 3 \\
2010 & 5 & 0 & 3 & 0 & 2 \\
2011 & 2 & 0 & 0 & 1 & 1 \\
2012 & 12 & 4 & 4 & 4 & 0 \\
2013 & 12 & 1 & 5 & 4 & 2 \\
2014 & 17 & 4 & 1 & 10 & 2 \\
2015 & 36 & 11 & 5 & 9 & 11 \\
2016 & 16 & 8 & 1 & 2 & 5 \\
2017 & 18 & 6 & 1 & 8 & 3 \\
2018 & 22 & 6 & 3 & 11 & 2 \\
Total & 146 & 41 & 25 & 49 & 31 \\
\hline
\end{tabular}

Panel B: Average fine amount $(\$ \mathrm{~m})$

\begin{tabular}{rlllll}
\hline & Fine & Fine_Banking & Fine_Economic & Fine_Market & Fine_Admin \\
\cline { 2 - 6 } 2009 & 80.663 & 8.385 & 392.000 & 0.000 & 0.977 \\
2010 & 270.454 & 0.000 & 266.200 & 0.000 & 276.835 \\
2011 & 72.524 & 0.000 & 0.000 & 145.000 & 0.048 \\
2012 & 915.638 & 1010.500 & 537.000 & 189.183 & 0.000 \\
2013 & 521.408 & 50.000 & 34.010 & 1202.685 & 7.815 \\
2014 & 292.976 & 107.540 & 258.661 & 394.500 & 41.500 \\
2015 & 1652.255 & 333.330 & 2575.298 & 912.435 & 34.043 \\
2016 & 137.744 & 201.075 & 2.486 & 0.655 & 4.592 \\
2017 & 2043.182 & 98.387 & 425.000 & 2677.320 & 48.562 \\
2018 & 1347.132 & 134.312 & 852.467 & 1415.925 & 445.895 \\
Total & 872.710 & 248.862 & 791.136 & 1093.701 & 76.034 \\
& & & & \\
\hline
\end{tabular}

Panel C: Total fine amount $(\$ \mathrm{~m})$

\begin{tabular}{rlllll}
\hline & Fine & Fine_Banking & Fine_Economic & Fine_Market & Fine_Admin \\
\cline { 2 - 6 } 2009 & 403.315 & 8.385 & 392.000 & 0.000 & 2.930 \\
2010 & 1352.269 & 0.000 & 798.600 & 0.000 & 553.669 \\
2011 & 145.048 & 0.000 & 0.000 & 145.000 & 0.048 \\
2012 & 3662.550 & 2021.000 & 1074.000 & 567.550 & 0.000 \\
2013 & 2607.039 & 50.000 & 136.038 & 2405.370 & 15.630 \\
2014 & 2636.781 & 322.620 & 258.661 & 1972.500 & 83.000 \\
2015 & 16522.545 & 2333.311 & 10301.193 & 3649.740 & 238.301 \\
2016 & 826.462 & 804.300 & 2.486 & 1.310 & 18.367 \\
2017 & 14302.272 & 393.548 & 425.000 & 13386.600 & 97.124 \\
2018 & 10777.057 & 537.250 & 852.467 & 8495.550 & 891.790 \\
Total & 53235.338 & 6470.414 & 14240.445 & 30623.620 & 1900.858
\end{tabular}

The table reports the summary statistics on misconduct fines of the sampled banks over the sample period (by year and in total). The statistics are reported for: (i) all misconduct fines and separately for those related to (ii) banking business violations, (iii) economic sanction violations, (iv) market violations, and (v) administrative violations. Panel A reports the number of fines; Panel B reports the average amount of fines; and Panel C reports the total amount of fines. Definitions of the variables are provided in Appendix B. 
Table 4: Univariate analysis by board gender diversity.

\begin{tabular}{|c|c|c|c|c|c|c|}
\hline & \multicolumn{2}{|c|}{ High gender diversity } & \multicolumn{2}{|c|}{ Low gender diversity } & \multicolumn{2}{|c|}{ Difference-in-means } \\
\hline & & & & & Diff & $p$-value \\
\hline D.Fine & 342 & 0.135 & 425 & 0.035 & -0.099 & $0.000 * * *$ \\
\hline N.Fine & 342 & 0.354 & 425 & 0.059 & -0.295 & $0.000 * * *$ \\
\hline Fine (m) & 342 & 143.846 & 425 & 9.505 & -134.34 & $0.001 * * *$ \\
\hline Female CEO & 342 & 0.100 & 425 & 0.019 & -0.081 & $0.000 * * *$ \\
\hline Female Chair & 341 & 0.419 & 425 & 0.124 & -0.294 & $0.000 * * *$ \\
\hline Female Leader & 342 & 0.456 & 425 & 0.137 & -0.32 & $0.000 * * *$ \\
\hline Board Size & 342 & 16.304 & 425 & 16.101 & -0.203 & 0.636 \\
\hline Director Tenure & 342 & 6.343 & 425 & 6.201 & -0.143 & 0.479 \\
\hline Director Age & 342 & 58.812 & 425 & 58.222 & -0.590 & $0.070 *$ \\
\hline CEO Tenure & 342 & 6.12 & 425 & 5.979 & -0.141 & 0.715 \\
\hline CEO Age & 342 & 55.661 & 425 & 56.76 & 1.099 & $0.036 * *$ \\
\hline CEO Turnover & 342 & 0.146 & 425 & 0.139 & -0.007 & 0.771 \\
\hline Director Age Diversity & 342 & 0.136 & 425 & 0.15 & 0.015 & $0.000 * * *$ \\
\hline Foreign Directors \% & 342 & 0.202 & 425 & 0.201 & -0.001 & 0.957 \\
\hline Employee Representative \% & 342 & 0.099 & 425 & 0.057 & -0.042 & $0.000 * * *$ \\
\hline Total Assets (bn) & 296 & 462.507 & 415 & 218.606 & -243.901 & $0.000 * * *$ \\
\hline$R O E$ & 296 & 0.062 & 415 & 0.054 & -0.007 & 0.327 \\
\hline Stock Return Volatility & 342 & 0.339 & 423 & 0.416 & 0.077 & $0.000 * * *$ \\
\hline Tobin's $Q$ & 294 & 1.65 & 412 & 2.502 & 0.853 & $0.001 * * *$ \\
\hline
\end{tabular}

The table reports the results of the univariate analysis by gender diversity of the board, where a bank is assigned to the high gender diversity sub-sample in year $t$ if the fraction of female directors on its board in year $t-1$ is equal to or greater than the sample median, and to the low gender diversity sub-sample otherwise. The t-test for the equality of means is reported in the last column, where *,**, *** indicate significance at the $1 \%, 5 \%, 10 \%$ level, respectively. Definitions of the variables are provided in Appendix B. 
Table 5: Board gender diversity and bank misconduct - Baseline regressions.

\begin{tabular}{|c|c|c|c|}
\hline & $\begin{array}{l}\text { N.Fine } \\
\text { (1) }\end{array}$ & $\begin{array}{l}\text { N.Fine } \\
\text { (2) }\end{array}$ & $\begin{array}{l}\text { N.Fine } \\
\text { (3) }\end{array}$ \\
\hline \multirow[t]{2}{*}{ Female Director \% } & $-1.293 *$ & $-1.259 *$ & $-1.731 *$ \\
\hline & $(0.743)$ & $(0.740)$ & $(0.950)$ \\
\hline \multirow[t]{2}{*}{ Gender Index Rank } & & -0.019 & \\
\hline & & $(0.043)$ & \\
\hline \multirow[t]{2}{*}{ Female Leader } & & & -0.366 \\
\hline & & & $(0.253)$ \\
\hline \multirow[t]{2}{*}{ N.Fine } & $0.235 * * *$ & $0.244 * * *$ & $0.275^{* * *}$ \\
\hline & $(0.079)$ & $(0.085)$ & $(0.075)$ \\
\hline \multirow[t]{2}{*}{ Ln(Fine) } & $-0.026^{*}$ & $-0.027 *$ & $-0.034 * *$ \\
\hline & $(0.014)$ & $(0.014)$ & $(0.014)$ \\
\hline \multirow[t]{2}{*}{ Ln(Board Size) } & 0.178 & 0.132 & 0.217 \\
\hline & $(0.255)$ & $(0.273)$ & $(0.240)$ \\
\hline \multirow{2}{*}{ Ln(Director Tenure) } & 0.580 & 0.639 & 0.564 \\
\hline & $(0.396)$ & $(0.453)$ & $(0.404)$ \\
\hline \multirow[t]{2}{*}{ Ln(Director Age) } & -2.653 & -3.257 & -2.752 \\
\hline & $(1.983)$ & $(2.557)$ & $(1.932)$ \\
\hline \multirow[t]{2}{*}{ Ln(CEO Tenure $)$} & $0.731 * * *$ & $0.731 * * *$ & $0.764 * * *$ \\
\hline & $(0.252)$ & $(0.247)$ & $(0.218)$ \\
\hline \multirow[t]{2}{*}{$\operatorname{Ln}(C E O A g e)$} & -0.961 & -1.050 & -1.662 \\
\hline & $(0.937)$ & $(1.036)$ & $(1.249)$ \\
\hline \multirow[t]{2}{*}{ CEO Turnover } & 0.310 & 0.294 & 0.312 \\
\hline & $(0.537)$ & $(0.512)$ & $(0.489)$ \\
\hline \multirow[t]{2}{*}{ Size } & $1.311 * * *$ & $1.344 * * *$ & $1.438 * * *$ \\
\hline & $(0.216)$ & $(0.250)$ & $(0.276)$ \\
\hline \multirow[t]{2}{*}{$R O E$} & 0.278 & 0.298 & 0.058 \\
\hline & $(1.575)$ & $(1.579)$ & $(1.142)$ \\
\hline \multirow[t]{2}{*}{ Stock Return Volatility } & $1.938 * *$ & $1.867 * *$ & $2.139 * * *$ \\
\hline & $(0.776)$ & $(0.727)$ & $(0.732)$ \\
\hline \multirow[t]{2}{*}{$\operatorname{Ln}($ Tobin's $Q)$} & 0.122 & 0.096 & 0.045 \\
\hline & $(0.261)$ & $(0.243)$ & $(0.278)$ \\
\hline \multirow[t]{2}{*}{ GDP Growth } & -0.043 & -0.032 & -0.043 \\
\hline & $(0.106)$ & $(0.097)$ & $(0.104)$ \\
\hline \multirow[t]{2}{*}{ G10 } & 0.675 & $0.717^{*}$ & 0.602 \\
\hline & $(0.427)$ & $(0.422)$ & $(0.388)$ \\
\hline \multirow[t]{2}{*}{ Intercept } & $-26.439 * *$ & $-24.266 * *$ & $-26.518 * *$ \\
\hline & $(10.705)$ & $(11.896)$ & $(10.524)$ \\
\hline Year FE & Yes & Yes & Yes \\
\hline Agency FE & Yes & Yes & Yes \\
\hline IRR Female Director \% & 0.274 & 0.284 & 0.177 \\
\hline Observations & 765 & 765 & 765 \\
\hline Log-Likelihood & $-119.01 * * *$ & $-118.97 * * *$ & $-118.25^{* * *}$ \\
\hline Pseudo R-Squared & 0.62 & 0.62 & 0.62 \\
\hline
\end{tabular}

The table reports the results from the negative binomial model for the number of misconduct fines in year $t$. All independent variables are lagged by one year. Standard errors clustered at the country level are reported in parentheses. IRR indicates the Incidence Rate Ratio for the main variable in the analysis. Agency FE stands for the type of agency that issues the fine. The Log-Likelihood statistic pertains to the null hypothesis that the model coefficients are jointly zero. $* * *, * *, *$ denote significance at the $1 \%, 5 \%, 10 \%$ level, respectively. Definitions of the variables are provided in Appendix B. 
Table 6: Critical mass and female leadership.

\begin{tabular}{|c|c|c|c|c|c|}
\hline & $\begin{array}{l}\text { N.Fine } \\
(1)\end{array}$ & $\begin{array}{l}\text { N.Fine } \\
(2)\end{array}$ & $\begin{array}{c}\text { N.Fine } \\
(3)\end{array}$ & $\begin{array}{c}\text { N.Fine } \\
(4)\end{array}$ & $\begin{array}{c}\text { N.Fine } \\
(5)\end{array}$ \\
\hline Critical Mass & $\begin{array}{l}-0.734 * * \\
(0.324)\end{array}$ & $\begin{array}{c}-0.734 * * \\
(0.327)\end{array}$ & $\begin{array}{c}-0.807 * * * \\
(0.310)\end{array}$ & $\begin{array}{l}-0.871 * * \\
(0.347)\end{array}$ & \\
\hline Gender Index Rank & & $\begin{array}{l}-0.021 \\
(0.041)\end{array}$ & & & \\
\hline Female Leader & & & $\begin{array}{l}-0.382 \\
(0.254)\end{array}$ & $\begin{array}{l}-0.589 \\
(0.388)\end{array}$ & \\
\hline $\begin{array}{l}\text { Critical Mass x Female } \\
\text { Leader }\end{array}$ & & & & $\begin{array}{c}0.237 \\
(0.407)\end{array}$ & \\
\hline Female Director \% & & & & & $\begin{array}{l}-1.189 \\
(0.750)\end{array}$ \\
\hline $\begin{array}{l}\text { Female Director } \% \mathrm{x} \\
\text { Female Leader }\end{array}$ & & & & & $\begin{array}{c}-1.318 * * \\
(0.666)\end{array}$ \\
\hline N.Fine & $\begin{array}{c}0.255^{* * *} \\
(0.081)\end{array}$ & $\begin{array}{c}0.264 * * * \\
(0.085)\end{array}$ & $\begin{array}{l}0.303 * * * \\
(0.071)\end{array}$ & $\begin{array}{l}0.300 * * * \\
(0.072)\end{array}$ & $\begin{array}{l}0.286 * * * \\
(0.075)\end{array}$ \\
\hline Ln(Fine $)$ & $\begin{array}{c}-0.034 * * \\
(0.016)\end{array}$ & $\begin{array}{c}-0.034 * * \\
(0.016)\end{array}$ & $\begin{array}{c}-0.044 * * * \\
(0.016)\end{array}$ & $\begin{array}{l}-0.044 * * * \\
(0.017)\end{array}$ & $\begin{array}{c}-0.035^{* *} \\
(0.014)\end{array}$ \\
\hline Ln(Board Size) & $\begin{array}{c}0.432 \\
(0.300)\end{array}$ & $\begin{array}{c}0.379 \\
(0.301)\end{array}$ & $\begin{array}{l}0.519^{*} \\
(0.275)\end{array}$ & $\begin{array}{l}0.505 * * \\
(0.257)\end{array}$ & $\begin{array}{c}0.190 \\
(0.242)\end{array}$ \\
\hline Ln(Director Tenure) & $\begin{array}{c}0.496 \\
(0.334)\end{array}$ & $\begin{array}{c}0.563 \\
(0.397)\end{array}$ & $\begin{array}{c}0.482 \\
(0.362)\end{array}$ & $\begin{array}{c}0.469 \\
(0.387)\end{array}$ & $\begin{array}{c}0.651 \\
(0.436)\end{array}$ \\
\hline Ln(Director Age $)$ & $\begin{array}{l}-3.087 \\
(1.955)\end{array}$ & $\begin{array}{l}-3.759 \\
(2.331)\end{array}$ & $\begin{array}{l}-3.179 * \\
(1.889)\end{array}$ & $\begin{array}{l}-3.327^{*} \\
(1.857)\end{array}$ & $\begin{array}{l}-2.468 \\
(2.023)\end{array}$ \\
\hline Ln(CEO Tenure $)$ & $\begin{array}{l}0.737 * * * \\
(0.262)\end{array}$ & $\begin{array}{l}0.737 * * * \\
(0.258)\end{array}$ & $\begin{array}{l}0.761 * * * \\
(0.236)\end{array}$ & $\begin{array}{l}0.771 * * * \\
(0.216)\end{array}$ & $\begin{array}{l}0.729 * * * \\
(0.217)\end{array}$ \\
\hline $\operatorname{Ln}(C E O A g e)$ & $\begin{array}{l}-1.189 * \\
(0.689)\end{array}$ & $\begin{array}{l}-1.296 \\
(0.814)\end{array}$ & $\begin{array}{l}-1.865^{*} \\
(0.960)\end{array}$ & $\begin{array}{c}-1.947 * * \\
(0.955)\end{array}$ & $\begin{array}{l}-1.481 \\
(1.058)\end{array}$ \\
\hline CEO Turnover & $\begin{array}{c}0.341 \\
(0.545)\end{array}$ & $\begin{array}{c}0.321 \\
(0.517)\end{array}$ & $\begin{array}{c}0.355 \\
(0.506)\end{array}$ & $\begin{array}{c}0.373 \\
(0.480)\end{array}$ & $\begin{array}{c}0.271 \\
(0.478)\end{array}$ \\
\hline Size & $\begin{array}{l}1.348 * * * \\
(0.180)\end{array}$ & $\begin{array}{c}1.385 * * * \\
(0.216)\end{array}$ & $\begin{array}{c}1.471 * * * \\
(0.230)\end{array}$ & $\begin{array}{l}1.495 * * * \\
(0.223)\end{array}$ & $\begin{array}{l}1.389 * * * \\
(0.231)\end{array}$ \\
\hline$R O E$ & $\begin{array}{l}-0.401 \\
(1.965)\end{array}$ & $\begin{array}{c}-0.382 \\
(1.986)\end{array}$ & $\begin{array}{c}-0.651 \\
(1.505)\end{array}$ & $\begin{array}{c}-0.602 \\
(1.487)\end{array}$ & $\begin{array}{c}0.081 \\
(1.215)\end{array}$ \\
\hline Stock Return Volatility & $\begin{array}{c}1.132 \\
(0.920)\end{array}$ & $\begin{array}{c}1.055 \\
(0.856)\end{array}$ & $\begin{array}{c}1.348 \\
(0.840)\end{array}$ & $\begin{array}{l}1.440^{*} \\
(0.797)\end{array}$ & $\begin{array}{c}2.020 * * * \\
(0.775)\end{array}$ \\
\hline Ln(Tobin's Q) & $\begin{array}{c}0.112 \\
(0.211)\end{array}$ & $\begin{array}{c}0.081 \\
(0.184)\end{array}$ & $\begin{array}{c}0.052 \\
(0.206)\end{array}$ & $\begin{array}{c}0.063 \\
(0.191)\end{array}$ & $\begin{array}{c}0.027 \\
(0.275)\end{array}$ \\
\hline GDP Growth & $\begin{array}{l}-0.023 \\
(0.109)\end{array}$ & $\begin{array}{l}-0.011 \\
(0.101)\end{array}$ & $\begin{array}{l}-0.023 \\
(0.109)\end{array}$ & $\begin{array}{l}-0.028 \\
(0.109)\end{array}$ & $\begin{array}{l}-0.037 \\
(0.098)\end{array}$ \\
\hline G10 & $\begin{array}{c}0.590 \\
(0.458)\end{array}$ & $\begin{array}{c}0.637 \\
(0.438)\end{array}$ & $\begin{array}{c}0.494 \\
(0.436)\end{array}$ & $\begin{array}{c}0.481 \\
(0.434)\end{array}$ & $\begin{array}{l}0.678^{*} \\
(0.373)\end{array}$ \\
\hline Intercept & $\begin{array}{l}-24.827 * * \\
(11.148)\end{array}$ & $\begin{array}{l}-22.371 * \\
(11.599)\end{array}$ & $\begin{array}{l}-25.096^{* *} \\
(10.910)\end{array}$ & $\begin{array}{c}-25.451 * * \\
(10.946)\end{array}$ & $\begin{array}{c}-27.253 * * * \\
(10.565)\end{array}$ \\
\hline Year FE & Yes & Yes & Yes & Yes & Yes \\
\hline Agency FE & Yes & Yes & Yes & Yes & Yes \\
\hline Observations & 765 & 765 & 765 & 765 & 765 \\
\hline Log-Lik Full Model & $-117.95 * * *$ & $-117.90 * * *$ & $-117.14 * * *$ & $-117.07 * * *$ & $-118.05^{* * *}$ \\
\hline Pseudo R-Squared & 0.623 & 0.623 & 0.626 & 0.626 & 0.623 \\
\hline
\end{tabular}


Table 7: Board gender diversity and bank misconduct - Size effects.

\begin{tabular}{|c|c|c|c|}
\hline & $\begin{array}{c}\text { N.Fine } \\
\text { (1) }\end{array}$ & $\begin{array}{c}\text { N.Fine } \\
(2)\end{array}$ & $\begin{array}{c}\text { N.Fine } \\
(3)\end{array}$ \\
\hline Female Director $\%$ x Size $Q_{1}$ & $\begin{array}{l}-0.517 \\
(0.643)\end{array}$ & $\begin{array}{l}-0.506 \\
(0.655)\end{array}$ & $\begin{array}{l}-0.936 \\
(0.904)\end{array}$ \\
\hline Female Director \% x Size $Q_{234}$ & $\begin{array}{c}-9.702 * * * \\
(2.348)\end{array}$ & $\begin{array}{c}-9.743 * * * \\
(2.402)\end{array}$ & $\begin{array}{c}-9.835 * * * \\
(2.395)\end{array}$ \\
\hline Size $Q_{1}$ & $\begin{array}{c}10.910 * * * \\
(0.851)\end{array}$ & $\begin{array}{c}10.519 * * * \\
(0.853)\end{array}$ & $\begin{array}{c}11.030 * * * \\
(0.893)\end{array}$ \\
\hline Size $Q_{2}$ & $\begin{array}{c}12.209 * * * \\
(0.8210)\end{array}$ & $\begin{array}{c}11.830 * * * \\
(0.820)\end{array}$ & $\begin{array}{c}12.387 * * * \\
(0.970)\end{array}$ \\
\hline Size $Q_{3}$ & $\begin{array}{c}-5.298 * * * \\
(0.547)\end{array}$ & $\begin{array}{c}-5.295 * * * \\
(0.563)\end{array}$ & $\begin{array}{c}-5.641 * * * \\
(0.588)\end{array}$ \\
\hline Gender Index Rank & & $\begin{array}{l}-0.016 \\
(0.043)\end{array}$ & \\
\hline Female Leader & & & $\begin{array}{l}-0.253 \\
(0.253)\end{array}$ \\
\hline N.Fine & $\begin{array}{c}0.254 * * * \\
(0.076)\end{array}$ & $\begin{array}{c}0.262 * * * \\
(0.085)\end{array}$ & $\begin{array}{c}0.279 * * * \\
(0.070)\end{array}$ \\
\hline Ln(Fine) & $\begin{array}{c}-0.033 * * \\
(0.015)\end{array}$ & $\begin{array}{c}-0.033 * * \\
(0.015)\end{array}$ & $\begin{array}{c}-0.037 * * * \\
(0.014)\end{array}$ \\
\hline Ln(Board Size $)$ & $\begin{array}{c}0.155 \\
(0.248)\end{array}$ & $\begin{array}{c}0.116 \\
(0.280)\end{array}$ & $\begin{array}{c}0.184 \\
(0.247)\end{array}$ \\
\hline Ln(Director Tenure) & $\begin{array}{l}0.610 * \\
(0.365)\end{array}$ & $\begin{array}{c}0.654 \\
(0.440)\end{array}$ & $\begin{array}{c}0.578 \\
(0.395)\end{array}$ \\
\hline Ln(Director Age $)$ & $\begin{array}{l}-3.036 \\
(1.923)\end{array}$ & $\begin{array}{l}-3.590 \\
(2.809)\end{array}$ & $\begin{array}{l}-3.059 \\
(1.951)\end{array}$ \\
\hline $\operatorname{Ln}(C E O$ Tenure $)$ & $\begin{array}{c}0.679 * * * \\
(0.233)\end{array}$ & $\begin{array}{c}0.681 * * * \\
(0.231)\end{array}$ & $\begin{array}{c}0.713 * * * \\
(0.216)\end{array}$ \\
\hline $\operatorname{Ln}(C E O A g e)$ & $\begin{array}{l}-0.742 \\
(0.811)\end{array}$ & $\begin{array}{l}-0.832 \\
(0.920)\end{array}$ & $\begin{array}{l}-1.263 \\
(1.124)\end{array}$ \\
\hline CEO Turnover & $\begin{array}{c}0.375 \\
(0.521)\end{array}$ & $\begin{array}{c}0.363 \\
(0.498)\end{array}$ & $\begin{array}{c}0.366 \\
(0.492)\end{array}$ \\
\hline Size & $\begin{array}{c}1.052 * * * \\
(0.109)\end{array}$ & $\begin{array}{c}1.084 * * * \\
(0.146)\end{array}$ & $\begin{array}{c}1.212 * * * \\
(0.179)\end{array}$ \\
\hline$R O E$ & $\begin{array}{c}1.041 \\
(1.377)\end{array}$ & $\begin{array}{c}1.065 \\
(1.383)\end{array}$ & $\begin{array}{c}0.796 \\
(1.053)\end{array}$ \\
\hline Stock Return Volatility & $\begin{array}{l}1.911 * * \\
(0.759)\end{array}$ & $\begin{array}{l}1.841 * * \\
(0.721)\end{array}$ & $\begin{array}{c}2.028 * * * \\
(0.757)\end{array}$ \\
\hline $\operatorname{Ln}($ Tobin's $Q)$ & $\begin{array}{c}0.143 \\
(0.241)\end{array}$ & $\begin{array}{c}0.119 \\
(0.217)\end{array}$ & $\begin{array}{c}0.077 \\
(0.238)\end{array}$ \\
\hline GDP Growth & $\begin{array}{l}-0.067 \\
(0.095)\end{array}$ & $\begin{array}{l}-0.057 \\
(0.084)\end{array}$ & $\begin{array}{l}-0.067 \\
(0.093)\end{array}$ \\
\hline G10 & $\begin{array}{c}0.652 * * \\
(0.308)\end{array}$ & $\begin{array}{c}0.678 * * \\
(0.324)\end{array}$ & $\begin{array}{l}0.578 * \\
(0.299)\end{array}$ \\
\hline Intercept & $\begin{array}{c}-29.605 * * * \\
(9.496)\end{array}$ & $\begin{array}{c}-27.220 * * \\
(12.510)\end{array}$ & $\begin{array}{c}-31.731 * * * \\
(9.911)\end{array}$ \\
\hline Year FE & Yes & Yes & Yes \\
\hline Agency FE & Yes & Yes & Yes \\
\hline Observations & 765 & 765 & 765 \\
\hline Log-Likelihood & -116.231 & -116.200 & -115.902 \\
\hline Pseudo R-Squared & 0.628 & 0.629 & 0.629 \\
\hline
\end{tabular}

The table reports the results from the negative binomial model for the number of misconduct fines in year $t$ accounting for the size of the bank. Size $Q i, i=1,2,3,4$, represents banks in the $i^{\text {th }}$ quartile as grouped by asset value, where 1 stands for the top quartile. The interaction term Female Director \% x Size Qi is the key variable defined as the percentage of female directors in the $i^{\text {th }}$ size quartile. All independent variables are lagged by one year. Standard errors clustered at the country level are reported in parentheses. Agency FE stands for the type of agency that issues the fine. The Log-Likelihood statistic pertains to the null hypothesis that the model coefficients are jointly zero. ***, **, * denote significance at the $1 \%, 5 \%, 10 \%$ level, respectively. Definitions of the variables are provided in Appendix B. 
Table 8: Change in board gender diversity and bank misconduct.

\begin{tabular}{|c|c|c|c|}
\hline & $\begin{array}{c}\text { N.Fine } \\
\text { (1) }\end{array}$ & $\begin{array}{c}\text { N.Fine } \\
(2)\end{array}$ & $\begin{array}{c}\text { N.Fine } \\
(3)\end{array}$ \\
\hline$\Delta$ Female Director $\%$ & $\begin{array}{c}-2.968^{*} \\
(1.769)\end{array}$ & $\begin{array}{l}-3.067^{*} \\
(1.765)\end{array}$ & $\begin{array}{l}-3.072 * \\
(1.855)\end{array}$ \\
\hline Gender Index Rank & & $\begin{array}{l}-0.028 \\
(0.047)\end{array}$ & \\
\hline Female Leader & & & $\begin{array}{l}-0.326 \\
(0.228)\end{array}$ \\
\hline N.Fine & $\begin{array}{c}0.257 * * * \\
(0.081)\end{array}$ & $\begin{array}{c}0.270 * * * \\
(0.088)\end{array}$ & $\begin{array}{c}0.300 * * * \\
(0.078)\end{array}$ \\
\hline Ln(Fine) & $\begin{array}{l}-0.036^{* *} \\
(0.015)\end{array}$ & $\begin{array}{c}-0.037 * * \\
(0.015)\end{array}$ & $\begin{array}{c}-0.045^{* * *} \\
(0.015)\end{array}$ \\
\hline Ln(Board Size) & $\begin{array}{r}0.269 \\
(0.311)\end{array}$ & $\begin{array}{c}0.193 \\
(0.332)\end{array}$ & $\begin{array}{c}0.334 \\
(0.301)\end{array}$ \\
\hline Ln(Director Tenure) & $\begin{array}{c}0.500 \\
(0.393)\end{array}$ & $\begin{array}{c}0.591 \\
(0.459)\end{array}$ & $\begin{array}{c}0.482 \\
(0.404)\end{array}$ \\
\hline Ln(Director Age) & $\begin{array}{l}-2.266 \\
(2.430)\end{array}$ & $\begin{array}{l}-3.239 \\
(3.010)\end{array}$ & $\begin{array}{l}-2.245 \\
(2.406)\end{array}$ \\
\hline Ln(CEO Tenure) & $\begin{array}{c}0.662 * * \\
(0.263)\end{array}$ & $\begin{array}{c}0.667 * * \\
(0.262)\end{array}$ & $\begin{array}{c}0.670 * * * \\
(0.234)\end{array}$ \\
\hline $\operatorname{Ln}(C E O$ Age $)$ & $\begin{array}{l}-0.993 \\
(0.728)\end{array}$ & $\begin{array}{l}-1.153 \\
(0.876)\end{array}$ & $\begin{array}{c}-1.522 \\
(0.946)\end{array}$ \\
\hline CEO Turnover & $\begin{array}{c}0.287 \\
(0.560)\end{array}$ & $\begin{array}{c}0.270 \\
(0.532)\end{array}$ & $\begin{array}{c}0.282 \\
(0.525)\end{array}$ \\
\hline Size & $\begin{array}{c}1.290 * * * \\
(0.199)\end{array}$ & $\begin{array}{c}1.342 * * * \\
(0.244)\end{array}$ & $\begin{array}{c}1.385 * * * \\
(0.237)\end{array}$ \\
\hline$R O E$ & $\begin{array}{c}0.672 \\
(1.556)\end{array}$ & $\begin{array}{c}0.687 \\
(1.575)\end{array}$ & $\begin{array}{c}0.581 \\
(1.163)\end{array}$ \\
\hline Stock Return Volatility & $\begin{array}{c}2.230 * * * \\
(0.735)\end{array}$ & $\begin{array}{c}2.092 * * * \\
(0.664)\end{array}$ & $\begin{array}{c}2.500 * * * \\
(0.727)\end{array}$ \\
\hline $\operatorname{Ln}($ Tobin's $Q)$ & $\begin{array}{c}0.194 \\
(0.236)\end{array}$ & $\begin{array}{c}0.153 \\
(0.208)\end{array}$ & $\begin{array}{c}0.146 \\
(0.243)\end{array}$ \\
\hline GDP Growth & $\begin{array}{c}-0.072 \\
(0.105)\end{array}$ & $\begin{array}{c}-0.057 \\
(0.094)\end{array}$ & $\begin{array}{c}-0.078 \\
(0.102)\end{array}$ \\
\hline G10 & $\begin{array}{c}0.481 \\
(0.491)\end{array}$ & $\begin{array}{c}0.543 \\
(0.483)\end{array}$ & $\begin{array}{c}0.392 \\
(0.476)\end{array}$ \\
\hline Intercept & $\begin{array}{c}-27.598^{* *} \\
(12.154)\end{array}$ & $\begin{array}{l}-23.963^{*} \\
(13.229)\end{array}$ & $\begin{array}{c}-28.153 * * \\
(12.095)\end{array}$ \\
\hline Year FE & Yes & Yes & Yes \\
\hline Agency FE & Yes & Yes & Yes \\
\hline IRR $\Delta$ Female Director $\%$ & 0.0514 & 0.0466 & 0.0463 \\
\hline Observations & 672 & 672 & 672 \\
\hline Log-Likelihood & $-118.41 * * *$ & $-118.31 * * *$ & $-117.77 * * *$ \\
\hline Pseudo R-Squared & 0.611 & 0.611 & 0.611 \\
\hline
\end{tabular}

The table reports results from the negative binomial model for the number of misconduct fines in year $t$. The key variable is the change in the fraction of female directors, $\Delta$ Female Director $\%$. All independent variables are lagged by one year. Standard errors clustered at the country level are reported in parentheses. IRR indicates the Incidence Rate Ratio for the main variable in the analysis. Agency FE stands for the type of agency that issues the fine. The Log-Likelihood statistic pertains to the null hypothesis that the model coefficients are jointly zero. $* * *, * *, *$ denote significance at the $1 \%, 5 \%, 10 \%$ level, respectively. Definitions of the variables are provided in Appendix B. 
Table 9: Ethical / risk aversion channel - Criminal vs civil fines.

\begin{tabular}{|c|c|c|c|c|c|}
\hline & $\begin{array}{c}\text { D.Fine } \\
\text { Criminal } \\
(1)\end{array}$ & $\begin{array}{c}\text { D.Fine } \\
\text { Criminal } \\
(2)\end{array}$ & $\begin{array}{c}\text { D.Fine } \\
\text { Criminal } \\
(3)\end{array}$ & $\begin{array}{c}\text { D.Fine } \\
\text { Criminal } \\
(4)\end{array}$ & $\begin{array}{c}\text { D.Fine } \\
\text { Criminal } \\
(5)\end{array}$ \\
\hline Female Director \% & $\begin{array}{c}-1.576^{*} \\
(0.884)\end{array}$ & $\begin{array}{l}-1.062 \\
(1.091)\end{array}$ & $\begin{array}{l}-1.138 \\
(1.515)\end{array}$ & $\begin{array}{c}5.528 \\
(4.103)\end{array}$ & $\begin{array}{l}-1.559 \\
(0.952)\end{array}$ \\
\hline Gender Index Rank & & $\begin{array}{l}-0.068 \\
(0.061)\end{array}$ & & & \\
\hline Female Leader & & & $\begin{array}{c}0.170 \\
(0.294)\end{array}$ & & \\
\hline $\begin{array}{l}\text { Female Director \% x Gender } \\
\text { Index Rank }\end{array}$ & & & & $\begin{array}{c}-0.414 * \\
(0.246)\end{array}$ & \\
\hline $\begin{array}{l}\text { Female Director } \% \text { x Female } \\
\text { Leader }\end{array}$ & & & & & $\begin{array}{c}0.811 \\
(1.195)\end{array}$ \\
\hline N.Fine & $\begin{array}{c}-0.084 \\
(0.312)\end{array}$ & $\begin{array}{l}-0.099 \\
(0.311)\end{array}$ & $\begin{array}{c}-0.079 \\
(0.286)\end{array}$ & $\begin{array}{l}-0.141 \\
(0.305)\end{array}$ & $\begin{array}{l}-0.055 \\
(0.247)\end{array}$ \\
\hline Ln(Fine) & $\begin{array}{l}0.068 * \\
(0.036)\end{array}$ & $\begin{array}{l}0.074 * \\
(0.040)\end{array}$ & $\begin{array}{c}0.070 * * \\
(0.035)\end{array}$ & $\begin{array}{c}0.078 * * \\
(0.035)\end{array}$ & $\begin{array}{c}0.066 * * \\
(0.032)\end{array}$ \\
\hline Board Controls & Yes & Yes & Yes & Yes & Yes \\
\hline Bank Controls & Yes & Yes & Yes & Yes & Yes \\
\hline Country Controls & Yes & Yes & Yes & Yes & Yes \\
\hline Year FE & Yes & Yes & Yes & Yes & Yes \\
\hline Agency FE & Yes & Yes & Yes & Yes & Yes \\
\hline Observations & 765 & 765 & 765 & 765 & 765 \\
\hline Log-Likelihood & $-23.06 * * *$ & $-22.87 * * *$ & $-23.01 * * *$ & $-22.68 * * *$ & $-22.98 * * *$ \\
\hline Pseudo R-Squared & 0.76 & 0.76 & 0.76 & 0.76 & 0.76 \\
\hline
\end{tabular}

The table reports the probit model results for the probability of receiving a criminal fine for misconduct in year $t$. All independent variables are lagged by one year. Standard errors clustered at the country level are reported in parentheses. Agency FE stands for the type of agency that issues the fine. The Log-Likelihood statistic pertains to the null hypothesis that the model coefficients are jointly zero. $* * *, * * *$ denote significance at the $1 \%, 5 \%$, $10 \%$ level, respectively. Definitions of the variables are provided in Appendix B. 
Table 10: CARs around misconduct fines announcement by type of misconduct.

\begin{tabular}{|c|c|c|c|}
\hline & $\begin{array}{c}\text { Announcement Window } \\
\text { (1) }\end{array}$ & $\begin{array}{c}\text { Market Reaction } \\
\text { (2) } \\
\end{array}$ & $\begin{array}{c}t \text {-Stat. } \\
(3)\end{array}$ \\
\hline \multirow[t]{7}{*}{ D.Fine_Banking } & $(0,5)$ & 0.012 & 1.03 \\
\hline & $(0,6)$ & 0.019 & 0.97 \\
\hline & $(0,7)$ & 0.016 & 0.58 \\
\hline & $(0,8)$ & 0.017 & 0.61 \\
\hline & $(0,9)$ & 0.017 & 0.63 \\
\hline & $(0,10)$ & 0.015 & 0.58 \\
\hline & $(0,15)$ & 0.017 & 1.01 \\
\hline \multirow[t]{7}{*}{ D.Fine_Economic } & $(0,5)$ & -0.026 & -1.56 \\
\hline & $(0,6)$ & -0.051 & $-1.92 *$ \\
\hline & $(0,7)$ & -0.076 & $-2.03 * *$ \\
\hline & $(0,8)$ & -0.076 & $-2.02 * *$ \\
\hline & $(0,9)$ & -0.076 & $-1.97 * *$ \\
\hline & $(0,10)$ & -0.060 & $-1.64 *$ \\
\hline & $(0,15)$ & 0.002 & 0.11 \\
\hline \multirow[t]{7}{*}{ D.Fine_Market } & $(0,5)$ & 0.010 & 1.03 \\
\hline & $(0,6)$ & 0.008 & 0.53 \\
\hline & $(0,7)$ & 0.011 & 0.50 \\
\hline & $(0,8)$ & 0.008 & 0.35 \\
\hline & $(0,9)$ & 0.004 & 0.20 \\
\hline & $(0,10)$ & 0.014 & 0.66 \\
\hline & $(0,15)$ & 0.013 & 0.91 \\
\hline \multirow[t]{7}{*}{ D.Fine_Admin } & $(0,5)$ & 0.014 & 1.10 \\
\hline & $(0,6)$ & 0.010 & 0.50 \\
\hline & $(0,7)$ & 0.016 & 0.53 \\
\hline & $(0,8)$ & 0.019 & 0.63 \\
\hline & $(0,9)$ & 0.022 & 0.71 \\
\hline & $(0,10)$ & 0.023 & 0.80 \\
\hline & $(0,15)$ & 0.026 & 1.42 \\
\hline
\end{tabular}

The table reports cumulative average abnormal returns (CARs) following the announcement of misconduct fines. For each type of fine, we report CARs over different event windows. The event study is based on 112 events. There are 39 cases of multiple sanctions, that is, concurrent fines from different agencies or of different type. On days with multiple misconduct announcements the type of misconduct is determined using the majority rule and, in the few cases of tie, by considering the amount of fine. Cumulative abnormal returns are based on constant expected return model estimated over the whole sample period. The $t$-statistics are derived based on the cross-sectional standard error of the abnormal returns. ***,**,* denote significance at the $1 \%, 5 \%, 10 \%$ level, respectively. Definitions of the variables are provided in Appendix B. 
Table 11: Ethical / risk aversion channel - Type of fine.

\begin{tabular}{lcccc}
\hline & $\begin{array}{c}\text { N.Fine_Banking } \\
(1)\end{array}$ & $\begin{array}{c}\text { N.Fine_Economic } \\
(2)\end{array}$ & $\begin{array}{c}\text { N.Fine_Market } \\
(3)\end{array}$ & $\begin{array}{c}\text { N.Fine_Admin } \\
(4)\end{array}$ \\
\hline & & & & \\
Female Director $\%$ & -2.486 & $-4.298^{* * *}$ & 1.260 & 1.407 \\
N.Fine & $(2.351)$ & $(1.235)$ & $(1.002)$ & $(2.330)$ \\
& 0.149 & $-0.556^{* *}$ & $-0.206^{*}$ & $-0.187^{* * *}$ \\
Ln(Fine) & $(0.284)$ & $(0.254)$ & $(0.116)$ & $(0.042)$ \\
& -0.025 & 0.036 & $0.050^{* * *}$ & 0.037 \\
Board Controls & $(0.055)$ & $(0.034)$ & $(0.015)$ & $(0.031)$ \\
Bank Controls & Yes & Yes & Yes & Yes \\
Country Controls & Yes & Yes & Yes & Yes \\
Year FE & Yes & Yes & Yes & Yes \\
Agency FE & Yes & Yes & Yes & Yes \\
Observations & Yes & Yes & Yes & Yes \\
Log-Likelihood & 765 & 765 & 765 & 765 \\
Pseudo R-Squared & $-53.78^{* * *}$ & $-60.64 * * *$ & $-55.02 * * *$ & $-52.45^{* * *}$ \\
\hline
\end{tabular}

The table reports the results from the negative binomial model for four types of misconduct fines in year $t$. The key variable is the fraction of female directors. All independent variables are lagged by one year. Standard errors clustered at the country level are reported in parentheses. Board controls include board size, directors' tenure and age, and CEO's tenure, age, and turnover. Bank controls include bank size, profitability, stock return volatility, and Tobin's Q. Country controls include gender index rank, GDP growth, and G10 indicator. Agency FE stands for the type of agency that issues the fine. The Log-Likelihood statistic pertains to the null hypothesis that the model coefficients are jointly zero. $* * *, * * *$ denote significance at the $1 \%, 5 \%, 10 \%$ level, respectively. Definitions of the variables are provided in Appendix B. 
Table 12: Diversity channel.

\begin{tabular}{|c|c|c|c|c|}
\hline & $\begin{array}{c}\text { N.Fine }_{t} \\
\text { (1) }\end{array}$ & $\begin{array}{c}\text { N.Fine } \\
\text { (2) }\end{array}$ & $\begin{array}{c}\text { N.Fine } \\
\text { (3) }\end{array}$ & $\begin{array}{c}\text { N.Fine } \\
\text { (4) }\end{array}$ \\
\hline Female Director \% & $\begin{array}{l}-1.724 * \\
(0.942)\end{array}$ & $\begin{array}{c}-1.561 * * * \\
(0.471)\end{array}$ & $\begin{array}{l}-1.766^{*} \\
(1.043)\end{array}$ & $\begin{array}{c}-1.659 * * * \\
(0.558)\end{array}$ \\
\hline Director Age Diversity & $\begin{array}{c}1.609 \\
(2.529)\end{array}$ & & & $\begin{array}{c}1.708 \\
(2.118)\end{array}$ \\
\hline Foreign Director \% & & $\begin{array}{l}-0.206 \\
(1.178)\end{array}$ & & $\begin{array}{l}-0.185 \\
(1.190)\end{array}$ \\
\hline Employee Representative \% & & & $\begin{array}{c}0.351 \\
(1.700)\end{array}$ & $\begin{array}{c}0.475 \\
(1.526)\end{array}$ \\
\hline Gender Index Rank & $\begin{array}{l}-0.019 \\
(0.050)\end{array}$ & $\begin{array}{l}-0.028 \\
(0.045)\end{array}$ & $\begin{array}{l}-0.032 \\
(0.062)\end{array}$ & $\begin{array}{l}-0.026 \\
(0.064)\end{array}$ \\
\hline Female Leader & $\begin{array}{l}-0.415 \\
(0.275)\end{array}$ & $\begin{array}{l}-0.377 \\
(0.255)\end{array}$ & $\begin{array}{l}-0.389 \\
(0.296)\end{array}$ & $\begin{array}{l}-0.430 \\
(0.278)\end{array}$ \\
\hline N.Fine & $\begin{array}{c}0.295 * * * \\
(0.082)\end{array}$ & $\begin{array}{c}0.290 * * * \\
(0.086)\end{array}$ & $\begin{array}{c}0.290 * * * \\
(0.090)\end{array}$ & $\begin{array}{c}0.300 * * * \\
(0.088)\end{array}$ \\
\hline Ln(Fine) & $\begin{array}{c}-0.035 * * \\
(0.014)\end{array}$ & $\begin{array}{c}-0.034 * * \\
(0.014)\end{array}$ & $\begin{array}{c}-0.035 * * \\
(0.016)\end{array}$ & $\begin{array}{c}-0.036 * * \\
(0.016)\end{array}$ \\
\hline Board Controls & Yes & Yes & Yes & Yes \\
\hline Bank Controls & Yes & Yes & Yes & Yes \\
\hline Country Controls & Yes & Yes & Yes & Yes \\
\hline Year FE & Yes & Yes & Yes & Yes \\
\hline Agency FE & Yes & Yes & Yes & Yes \\
\hline Observations & 765 & 765 & 765 & 765 \\
\hline Pseudo R-Squared & 0.622 & 0.622 & 0.622 & 0.623 \\
\hline Log-Likelihood & $-118.06 * * *$ & $-118.13 * * *$ & $-118.14 * * *$ & $-118.015 * * *$ \\
\hline
\end{tabular}

The table reports the results from the negative binomial model for misconduct fines in year $t$. The key variable is the fraction of female directors. Additional proxies for board diversity are added to test for the diversity channel. All independent variables are lagged by one year. Standard errors clustered at the country level are reported in parentheses. Board controls include board size, directors' tenure and age, and CEO's tenure, age, and turnover. Bank controls include bank size, profitability, stock return volatility, and Tobin's Q. Country controls include gender index rank, GDP growth, and G10 indicator. Agency FE stands for the type of agency that issues the fine. The Log-Likelihood statistic pertains to the null hypothesis that the model coefficients are jointly zero. $* * *, * * *$ denote significance at the $1 \%, 5 \%, 10 \%$ level, respectively. Definitions of the variables are provided in Appendix B. 
Table 13: Board gender diversity and bank misconduct - Country fixed effects.

\begin{tabular}{|c|c|c|c|c|c|c|}
\hline & $\begin{array}{c}\text { N.Fine } \\
\text { (1) }\end{array}$ & $\begin{array}{c}\text { N.Fine } \\
\text { (2) }\end{array}$ & $\begin{array}{c}\text { N.Fine } \\
\text { (3) }\end{array}$ & $\begin{array}{c}\text { N.Fine } \\
\text { (4) }\end{array}$ & $\begin{array}{c}\text { N.Fine } \\
\text { (5) }\end{array}$ & $\begin{array}{c}\text { N.Fine } \\
\text { (6) }\end{array}$ \\
\hline Female Director $\%$ x Size $Q_{1}$ & $\begin{array}{c}0.988 \\
(1.033)\end{array}$ & $\begin{array}{c}0.526 \\
(1.252)\end{array}$ & & & & \\
\hline Female Director \% x Size $Q_{234}$ & $\begin{array}{c}-7.226 * * \\
(2.813) \\
(17.567)\end{array}$ & $\begin{array}{c}-7.633^{* * *} \\
(2.687) \\
(22.035)\end{array}$ & & & & \\
\hline$\Delta$ Female Director $\%$ & & & $\begin{array}{c}-3.245^{* * * *} \\
(1.025)\end{array}$ & $\begin{array}{c}-3.140 * * * \\
(1.121)\end{array}$ & & \\
\hline Critical Mass & & & & & $\begin{array}{c}-0.656 * * \\
(0.326)\end{array}$ & $\begin{array}{c}-0.710 * * * \\
(0.247)\end{array}$ \\
\hline Female Leader & & $\begin{array}{l}-0.371 \\
(0.307)\end{array}$ & & $\begin{array}{l}-0.305 \\
(0.270)\end{array}$ & & $\begin{array}{l}-0.368 \\
(0.293)\end{array}$ \\
\hline N.Fine & $\begin{array}{c}0.211 * * \\
(0.088)\end{array}$ & $\begin{array}{c}0.246 * * * \\
(0.080)\end{array}$ & $\begin{array}{c}0.232 * * * \\
(0.085)\end{array}$ & $\begin{array}{c}0.261 * * * \\
(0.073)\end{array}$ & $\begin{array}{c}0.215^{* *} * \\
(0.091)\end{array}$ & $\begin{array}{c}0.254 * * * \\
(0.073)\end{array}$ \\
\hline Ln(Fine) & $\begin{array}{c}-0.034 * * \\
(0.014)\end{array}$ & $\begin{array}{c}-0.040 * * * \\
(0.014)\end{array}$ & $\begin{array}{c}-0.038 * * * \\
(0.014)\end{array}$ & $\begin{array}{c}-0.043 * * * \\
(0.013)\end{array}$ & $\begin{array}{c}-0.033 * * \\
(0.015)\end{array}$ & $\begin{array}{c}-0.040 * * * \\
(0.013)\end{array}$ \\
\hline Board Controls & Yes & Yes & Yes & Yes & Yes & Yes \\
\hline Bank Controls & Yes & Yes & Yes & Yes & Yes & Yes \\
\hline Year FE & Yes & Yes & Yes & Yes & Yes & Yes \\
\hline Agency FE & Yes & Yes & Yes & Yes & Yes & Yes \\
\hline Country FE & Yes & Yes & Yes & Yes & Yes & Yes \\
\hline Size FE & Yes & Yes & & & & \\
\hline Observations & 674 & 674 & 592 & 592 & 674 & 674 \\
\hline Log-Likelihood & $109.63 * * *$ & $108.91 * * *$ & $-109.96 * * *$ & $-109.44 * * *$ & $-109.84 * * *$ & $-109.11^{* * *}$ \\
\hline Pseudo R-Squared & 0.64 & 0.64 & 0.63 & 0.63 & 0.64 & 0.64 \\
\hline
\end{tabular}

The table reports the results from the negative binomial model with country fixed effects for the number of misconduct fines in year $t$. Size $Q i, i=1,2,3,4$, represents banks in the $i^{\text {th }}$ quartile as grouped by asset value, where 1 stands for the top quartile. In Models (1) and (2), the interaction term Female Director \% x Size Qi defines the percentage of female directors in the $i^{\text {th }}$ size quartile. Size FE denotes the size quartile indicators Size Qi. In Models (3) and (4), the key variable is the change in the fraction of female directors, $\Delta$ Female Director \%. In Models (5) and (6), the key variable is the critical mass dummy variable, Critical Mass. All independent variables are lagged by one year. Standard errors clustered at the country level are reported in parentheses. Board controls include board size, directors' tenure and age, and CEO's tenure, age, and turnover. Bank controls include bank size, profitability, stock return volatility, and Tobin's Q. Country controls include gender index rank, GDP growth, and G10 indicator. Agency FE stands for the type of agency that issues the fine. The Log-Likelihood statistic pertains to the null hypothesis that the model coefficients are jointly zero. $* * * * * *$ denote significance at the $1 \%, 5 \%, 10 \%$ level, respectively. Definitions of the variables are provided in Appendix B. 
Table 14: Testing for glass cliff effect - Sub-sample analysis.

\begin{tabular}{lccc}
\hline & $\begin{array}{c}\text { N.Fine } \\
(1)\end{array}$ & $\begin{array}{c}\text { N.Fine } \\
(2)\end{array}$ & $\begin{array}{c}\text { N.Fine } \\
(3)\end{array}$ \\
\hline Female Director \% & & & \\
& $-6.413^{* * *}$ & & \\
Female Director \% & $(1.913)$ & $-2.848^{*}$ & \\
& & $(1.470)$ & $-0.609 * * *$ \\
Critical Mass & & & $(1.025)$ \\
Gender Index Rank & & -0.064 & -0.063 \\
& -0.090 & $(0.063)$ & $(0.067)$ \\
Female Leader & $(0.075)$ & -0.437 & $-0.637^{*}$ \\
& $-0.944^{* * *}$ & $(0.356)$ & $(0.330)$ \\
N.Fine & $(0.352)$ & 0.236 & $0.526^{* * *}$ \\
& $0.531^{* * *}$ & $(0.255)$ & $(0.184)$ \\
Ln(Fine) & $(0.156)$ & -0.035 & $-0.050^{* * * *}$ \\
& $-0.040^{* * *}$ & $(0.077)$ & $(0.018)$ \\
Board Controls & $(0.015)$ & Yes & Yes \\
Bank Controls & Yes & Yes & Yes \\
Country Controls & Yes & Yes & Yes \\
Year FE & Yes & Yes & Yes \\
Agency FE & Yes & Yes & 310 \\
Observations & Yes & 404 & $-79.46^{* * * *}$ \\
Log-Likelihood & 490 & $-72.41^{* * *}$ & 0.64 \\
Pseudo R-Squared & $-77.87^{* * *}$ & 0.62 & \\
& 0.65 & &
\end{tabular}

The table reports the results from the negative binomial model for the number of misconduct fines in year $t$ for different proxies for gender diversity. The sub-sample only includes observations for which the change in the stock return volatility in the previous period is lower than the $75^{\text {th }}$ percentile. Standard errors clustered at the country level are reported in parentheses. Board controls include the board size, directors' tenure and age, and CEO's tenure, age, and turnover. Bank controls include the bank size, profitability, stock return volatility, and Tobin's Q. Country controls include the gender index rank, GDP growth, and G10 dummy variable. Agency FE stands for the type of agency that issues the fine. Asterisks next to the Log-Likelihood value represent rejection of the null hypothesis that the model coefficients are jointly zero. $* * *, * * *$ denote significance at the $1 \%, 5 \%$, $10 \%$ level, respectively. Definitions of the variables are provided in Appendix B. 
Table 15: Board gender diversity and bank misconduct - Probit regressions.

\begin{tabular}{|c|c|c|c|}
\hline & $\begin{array}{c}\text { D.Fine } \\
(1)\end{array}$ & $\begin{array}{l}\text { D.Fine } \\
(2)\end{array}$ & $\begin{array}{c}\text { D.Fine } \\
\text { (3) }\end{array}$ \\
\hline Female Director \% x Size $Q_{1}$ & $\begin{array}{c}1.443 \\
(0.929)\end{array}$ & $\begin{array}{c}1.444 \\
(0.947)\end{array}$ & $\begin{array}{l}1.756^{*} \\
(1.054)\end{array}$ \\
\hline Female Director \% x Size $Q_{234}$ & $\begin{array}{c}-5.470 * * * \\
(1.578) \\
(9.032)\end{array}$ & $\begin{array}{c}-5.473 * * * \\
(1.638) \\
(12.179)\end{array}$ & $\begin{array}{c}-5.396 * * * \\
(1.398) \\
(9.176)\end{array}$ \\
\hline Gender Index Rank & & $\begin{array}{c}-0.001 \\
(0.062)\end{array}$ & \\
\hline Female Leader & & & $\begin{array}{l}0.407 * \\
(0.244)\end{array}$ \\
\hline N.Fine & $\begin{array}{c}0.004 \\
(0.109)\end{array}$ & $\begin{array}{c}0.005 \\
(0.119)\end{array}$ & $\begin{array}{c}-0.014 \\
(0.094)\end{array}$ \\
\hline Ln(Fine) & $\begin{array}{c}0.017 \\
(0.020)\end{array}$ & $\begin{array}{c}0.017 \\
(0.021)\end{array}$ & $\begin{array}{c}0.020 \\
(0.020)\end{array}$ \\
\hline Board Controls & Yes & Yes & Yes \\
\hline Bank Controls & Yes & Yes & Yes \\
\hline Country Controls & Yes & Yes & Yes \\
\hline Year FE & Yes & Yes & Yes \\
\hline Size FE & Yes & Yes & Yes \\
\hline Observations & 765 & 765 & 765 \\
\hline Log-Likelihood & $-82.65 * * *$ & $-82.65 * * *$ & $-80.78 * * *$ \\
\hline Pseudo R-Squared & 0.61 & 0.61 & 0.62 \\
\hline
\end{tabular}

The table reports the results from the probit model for the incidence of misconduct fine in year $t$. Gender diversity is proxied by the fraction of female directors on the board. Size Qi, $i=1,2,3$, 4, represents banks in the $i^{\text {th }}$ quartile as grouped by asset value, where 1 stands for the top quartile. The interaction term Female Director \% x Size $Q i$ is the key variable defined as the percentage of female directors in the $i^{\text {th }}$ size quartile. Size FE denotes the size quartile indicators Size Qi. All independent variables are lagged by one year. Standard errors clustered at the country level are reported in parentheses. Board controls include board size, directors' tenure and age, and CEO's tenure, age, and turnover. Bank controls include bank size, profitability, stock return volatility, and Tobin's Q. Country controls include gender index rank, GDP growth, and G10 dummy variable. Agency FE stands for the type of agency that issues the fine. The Log-Likelihood statistic pertains to the null hypothesis that the model coefficients are jointly zero. $* * *, * *, *$ denote significance at the $1 \%, 5 \%, 10 \%$ level, respectively. Definitions of the variables are provided in Appendix B. 


\section{References}

Adams, R. B. and Ferreira, D. (2007) A Theory of Friendly Boards, Journal of Finance 62(1), 217 250.

Adams, R. B. and Ferreira, D. (2009) Women in the boardroom and their impact on governance and performance, Journal of Financial Economics 94, 291-309.

Adams, R. B. and Ferreira, D. (2012) Regulatory Pressure and Bank Directors' Incentives to Attend Board Meetings, International Review of Finance, 12(2), 227-248

Adams, R. B., Licht, A.N. and Sagiv, L., (2011) Shareholderism: Board Members' Values and the Shareholder-Stakeholder Dilemma, Strategic Management Journal, 32, 1331-1355.

Adams, R.B., Funk, P. (2012) Beyond the glass ceiling: does gender matter? Management Science 58, 219-235.

Agarwal, S., Lucca, D., Seru, A., Trebbi, F., 2014. Inconsistent regulators: Evidence from banking. Quarterly Journal of Economics 129, 889-938.

Ahern, K. R. and A. K. Dittmar (2012) The changing of the boards: The impact on firm valuation of mandated female board representation. Quarterly Journal of Economics 127, 137-197.

Alesina, A., P. Giuliano, P., and N. Nunn (2013) On the Origins of Gender Roles: Women and the Plough. Quarterly Journal of Economics 128, 469-530.

Algan, Y., C. Hemet and D.D. Laitin, 2016, The Social Effects of Ethnic Diversity at the Local Level. Journal of Political Economy, 124, 696-733.

Anderson, R.C., Reeb, D.M., Upadhyay, A., Zhao, W., 2011. The economics of director heterogeneity. Financial Management 40, 5-38.

Arnaboldi, F., Casu, B., Kalotychou, E., Sarkisyan, A. (2018) The performance effects of board heterogeneity: what works for EU banks?, The European Journal of Finance, 10.1080/1351847X.2018.1479719, (1-28), (2018).

Basel Committee on Banking Supervision (BCBS) (2015). Corporate governance principles for banks. Bank for International Settlements (BIS), Basel. https://www.bis.org/bcbs/publ/d328.pdf

Beasley, M. (1996). An Empirical Analysis of the Relation between the Board of Director Composition and Financial Statement Fraud. The Accounting Review, 71(4), 443-465.

Beltratti A. and Stulz, R. M. (2012) The credit crisis around the globe: Why did some banks perform better?, Journal of Financial Economics 105(1), 1-17.

Bennouri, M., Chtiouib, T., Nagati, H., and Nekhili, M. (2018) Female board directorship and firm performance: What really matters? Journal of Banking and Finance 88, 267-291.

Brown, S. and Warner, J. (1985) Using daily stock returns: the case of event studies. Journal of Financial Economics 14, 3-31.

Byron, K., and Post, C. (2016) Women on boards of directors and corporate social performance: a meta-analysis. Corporate Governance. An International Review, 24(4), 428-442.

Campbell, K., and Minguez-Vera, A. (2008) Gender diversity in the boardroom and firm financial performance. Journal of Business Ethics, 83(3), 435-451.

Carter, D.A., D'Souza, F.P, Simkins, B.J., and Simpson, W.G. (2010) The Gender and Ethnic Diversity of US Boards and Board Committees and Firm Financial Performance, Corporate Governance 18(5), 396 - 414. 
Carter, D.A., Simkins, B.J., and Simpson, W.G. (2003) Corporate Governance, Board Diversity and Firm Value, Financial Review 38, 33-53.

Conduct Cost Project (CCP) Research Foundation (2017). http://conductcosts.ccpresearchfoundation.com

Croson, R., Gneezy, U., (2009). Gender differences in preferences. Journal of Economic Literature, $47,448-474$.

Cumming, D., Leung, T.Y., Rui, O. (2015). Gender diversity and securities fraud. Academy of Management Journal, 58 (5), 1572-1593.

Danisewicz, P., McGowan, D., Onali, E., Schaeck, K., 2018. The real effects of banking supervision: Evidence from enforcement actions. Journal of Financial Intermediation 35, 86-101.

Deli, Y., Delis, M.D., Hasan, I., Liu, L. (2019) Enforcement of banking regulation and the cost of borrowing. Journal of Banking \& Finance, forthcoming.

Delis, M.D., Staikouras, P., Tsoumas, C., 2017. Enforcement actions and bank behaviour. Management Science 63, 959-987.

Della Vigna, S. List, J.A., Malmendier, U., Rao, G. (2013) The Importance of Being Marginal: Gender Differences in Generosity. American Economic Review Papers and Proceedings, May 2013.

Dittmann, I., Maug, E., Schneider, C. (2010), Bankers on the Boards of German Firms: What They Do, What They Are Worth, and Why They Are (Still) There, Review of Finance, 14 (1), 35 71.

Egan, M. L., Matvos, G., Seru, A. (2018) When Harry fired Sally: the double standard in punishing misconduct. NBER Working Paper Series, WP 23242. http://www.nber.org/papers/w23242

Eckel, C.C., Fuellbrunn, S.C. (2015) Thar she blows? Gender, competition, and bubbles in experimental asset markets, American Economic Review 105, 906-920.

Ellul, A. and Yerramilli, V. (2013) Strong risk controls, lower risk: evidence from US bank holding companies, Journal of Finance 68, 1757-1803.

European Banking Authority (2017). Joint ESMA and EBA Guidelines on the assessment of the suitability of members of the management body and key function holders under Directive 2013/36/EU and Directive 2014/65/EU, September. Retrieved from https://eba.europa.eu/documents/10180/1972984/Joint+ESMA+and+EBA+Guidelines+on+th e+assessment+of+suitability+of+members+of +the+management+body+and+key+function $+\mathrm{h}$ olders+\%28EBA-GL-2017-12\%29.pdf

European Systemic Risk Board (ESRB) (2015) Report on misconduct risk in the banking sector. June 2015. https://www.esrb.europa.eu/pub/pdf/other/150625_report_misconduct_risk.en.pdf

Fahlenbrach R., Low A. and Stulz R. (2017) Do independent director departures predict future bad events?, Review of Financial Studies 30(7), 2313-2358.

Fenergo (2018) A fine mess we're in. AML/KYC/Sanction Fines. A ten-year analysis (2008-2018). www.fenergo.com

Fields, M., and Keys, P., (2003) The emergence of corporate governance from Wall St. to Main St.: outside directors, board diversity, earnings management, and managerial incentives to bear risk, Financial Review 38, 1-24.

García Lara, J.M., García Osma, B., Mora, A. and Scapin, M. (2017) The monitoring role of female directors over accounting quality. Journal of Corporate Finance, 45, 651-668. 
Giannetti, M., Zhao, M. (2018) Board Ancestral Diversity and Firm Performance Volatility. Journal of Financial and Quantitative Analysis, forthcoming.

Gul, F.A., Srinidhi, B., Ng, A.C. (2011) Does board gender diversity improve the informativeness of stock prices?, Journal of Accounting and Economics 51, 314-338.

Hermalin, B E., and Weisbach, M. (2003) Boards of directors as an endogenously determined institution: A survey of the economic literature, Economic Policy Review 9, 7-26.

Ioannidou, V., (2005) Does monetary policy affect the central bank's role in bank supervision? Journal of Financial Intermediation 14, 58-85.

Jianakoplos, N.A., Bernasek, A., 1998. Are women more risk averse? Economic Inquiry 36 (4), 620630.Levi, M., Li, K., Zhang, F. (2014). Director gender and mergers and acquisitions. Journal of Corporate Finance, 28, 185-200.

Li N. \& Wahid, A.S. (2017). Director Tenure Diversity and Board Monitoring Effectiveness, Contemporary Accounting Research, 35, 1363-1394.

Liu, C. (2018) Are women greener? Corporate gender diversity and environmental violations. Journal of Corporate Finance, 52, 118-142.

Liu, Y., Wei, Z., Xie, F. (2014). Do women directors improve firm performance in China? Journal of Corporate Finance, 28, 169-184.

Masulis, R. W., C. Wang, and F. Xie, 2012, Globalizing the boardroom-The effects of foreign directors on corporate governance and firm performance, Journal of Accounting and Economics, 53, 527-554.

Mateos de Cabo R., Gimeno R., and Nieto M.J. (2012) Gender diversity on European banks' boards of directors, Journal of Business Ethics 109(2), 145-162.

Matsa, D.A., Miller, A.R., 2011. Chipping away at the glass ceiling: gender spillovers in corporate leadership. American Economic Review: Papers and Proceedings 101, 635-639.

Matsa, D.A., Miller, A.R., 2013. A female style in corporate leadership? Evidence from quotas. American Economic Review: Applied Economics 5, 136-169.

McGuinness, P.b., Vieito, J.P., and Wang M. (2017) The role of board gender and foreign ownership in the CSR performance of Chinese listed firms. Journal of Corporate Finance, 42, 75-99.

Nelson J. (2014) Are Women Really More Risk-Averse than Men? A Re-Analysis of the Literature Using Expanded Methods, Journal of Economic Surveys 29 566-85.

Nguyen, D.D., Hagendorff, J., Eshraghi, A. (2016) Can Bank Boards Prevent Misconduct? Review of Finance, 20(1), 1-36.

Oxelheim L., Gregoric A., Rabdoy T., and Thomsen S. (2013) On the internationalization of corporate boards: The case of Noridc firms, Journal of International Business Studies 44, 173-194.

Price, C.R. (2012) Gender, competition, and managerial decisions, Management Science 58, 114-122.

Richardson, G., Taylor, G., Lanis, R. (2016) Women on the board of directors and corporate tax aggressiveness in Australia: an empirical analysis. Accounting Research Journal 29 (3), 313331.

Robinson, G., Dechant, K. (1997) Building a Business Case for Diversity, Academy of Management Executive, 11(3), 21-31.

Ryan, M.K., Haslam S.A. (2005) The Glass Cliff: Evidence that Women are Over-Represented in Precarious Leadership Positions. British Journal of Management, 16, 81-90. 
Sahay, R., Cihak, M. (2018) Women in Finance: a case for closing the gap. IMF Discussion Note, September 2019, SDN/18/05.

Sapienza, P., Zingales, L., Maestripieri, D., 2009. Gender differences in financial risk aversion and career choices are affected by testosterone. Proceedings National Academy of Science 106, $15268-15273$.

Schubert, R., Brown, M., Gysler, M., Brachinger, H.W. (1999) Financial Decision-Making: Are Women Really More Risk-Averse? American Economic Review, 89(2): 381-85.

Sila, V., Gonzalez, A., Hagendorff, J. (2016) Women on board: Does boardroom gender diversity affect firm risk? Journal of Corporate Finance, 36, 26-53.

Stigler, G.J. (1971) The theory of economic regulation. The Bell Journal of Economics and Management Science, 2(1), 3-21.

Terjesen, S., Sealy, R., and Singh, V. (2009). Women Directors on Corporate Boards: A Review and Research Agenda. Corporate Governance. An International Review, 17 (3), 320-337.

Ye, D., Deng, J., Liu, Y., Szewczyk, S.H., and Chen, X. (2019) Does board gender diversity increase dividend payouts? Analysis of global evidence, Journal of Corporate Finance 58, 1-26. 
Appendix A: List of sampled sanctions and sanctioning regulatory agencies.

\begin{tabular}{|c|c|c|}
\hline Sanction type & Sanction & Sanctioning regulatory agency \\
\hline \multirow{12}{*}{$\begin{array}{l}\text { Banking business } \\
\text { violations }\end{array}$} & \multirow[t]{3}{*}{ Banking violation } & Office of the Comptroller of the Currency (OCC) \\
\hline & & Federal Reserve \\
\hline & & $\begin{array}{l}\text { New York State Department of Financial } \\
\text { Services (NYSDFS) } \\
\text { New York County District Attorney (NYCDA) }\end{array}$ \\
\hline & \multirow[t]{3}{*}{ Anti-money laundering deficiency } & Federal Reserve \\
\hline & & Justice Department Criminal Division \\
\hline & & $\begin{array}{l}\text { New York State Department of Financial } \\
\text { Services (NYSDFS) }\end{array}$ \\
\hline & Fraud & Justice Department Criminal Division \\
\hline & \multirow[t]{2}{*}{ Mortgage abuse } & US Attorney \\
\hline & & Justice Department multiagency referral \\
\hline & $\begin{array}{l}\text { Financial institution supervision } \\
\text { failure }\end{array}$ & Commodity Futures Trading Commission \\
\hline & \multirow[t]{2}{*}{ Investor protection violation } & Securities and Exchange Commission (SEC) \\
\hline & & Commodity Futures Trading Commission \\
\hline \multirow{6}{*}{$\begin{array}{l}\text { Economic sanction } \\
\text { violations }\end{array}$} & \multirow[t]{5}{*}{ Economic sanction violation } & Justice Department Criminal Division \\
\hline & & Office of Foreign Assets Control \\
\hline & & US Attorney \\
\hline & & $\begin{array}{l}\text { New York State Department of Financial } \\
\text { Services (NYSDFS) } \\
\text { Federal Reserve }\end{array}$ \\
\hline & & Office of Foreign Assets Control \\
\hline & US sanction violation & Office of Foreign Assets Control \\
\hline \multirow[t]{14}{*}{ Market violations } & \multirow[t]{5}{*}{ Toxic securities abuse } & Federal Housing Finance Agency \\
\hline & & National Credit Union Administration \\
\hline & & US Attorney \\
\hline & & Justice Department Civil Division \\
\hline & & Securities and Exchange Commission (SEC) \\
\hline & \multirow{2}{*}{$\begin{array}{l}\text { Securities issuance or trading } \\
\text { violation }\end{array}$} & Securities and Exchange Commission (SEC) \\
\hline & & Commodity Futures Trading Commission \\
\hline & \multirow{3}{*}{$\begin{array}{l}\text { Interest rate benchmark } \\
\text { manipulation }\end{array}$} & Justice Department Criminal Division \\
\hline & & Commodity Futures Trading Commission \\
\hline & & Federal Reserve \\
\hline & \multirow{3}{*}{$\begin{array}{l}\text { Foreign exchange market } \\
\text { manipulation }\end{array}$} & Justice Department Criminal Division \\
\hline & & Federal Reserve \\
\hline & & Justice Department Antitrust Division \\
\hline & Energy market manipulation & Federal Energy Regulatory Commission \\
\hline \multirow{3}{*}{$\begin{array}{l}\text { Administrative } \\
\text { violations }\end{array}$} & \multirow[t]{2}{*}{ Tax violation } & Justice Department Tax Division \\
\hline & & US Attorney \\
\hline & Accounting fraud or deficiency & Commodity Futures Trading Commission \\
\hline
\end{tabular}


Falsification of records of NY

financial institutions

Data submission deficiency

False Claims Act

Consumer protection violation

Employment discrimination

Benefit plan administrator violation

Wage and hour violation

Workplace safety or health violation

Servicemembers Civil Relief Act

Environmental violation
New York County District Attorney (NYCDA)

Commodity Futures Trading Commission

Justice Department Civil Division

US Attorney

Consumer Financial Protection Bureau

Equal Employment Opportunity Commission

Employee Benefits Security Administration

Labour Department Wage and Hour Division

Occupational Safety \& Health Administration

Justice Department Civil Rights Division

Environmental Protection Agency

The table presents the list of sampled sanctions by type and relevant sanctioning regulatory agencies. 
Appendix B: Variable definitions.

\begin{tabular}{|c|c|c|}
\hline Variable & Definition & Source \\
\hline \multicolumn{3}{|l|}{ Misconduct fines } \\
\hline D.Fine & $\begin{array}{l}\text { Dummy variable equal to } 1 \text { if a bank has been } \\
\text { fined in year } t \text {, and } 0 \text { otherwise }\end{array}$ & $\begin{array}{l}\text { Authors' calculation using Violation } \\
\text { Tracker / Regulatory agency data }\end{array}$ \\
\hline N.Fine & Number of fines (total) in a bank year & $\begin{array}{l}\text { Authors' calculation using Violation } \\
\text { Tracker / Regulatory agency data }\end{array}$ \\
\hline N.Fine_Banking & $\begin{array}{l}\text { Number of fines related to banking business } \\
\text { violations }\end{array}$ & $\begin{array}{l}\text { Authors' calculation using Violation } \\
\text { Tracker / Regulatory agency data }\end{array}$ \\
\hline N.Fine_Economic & $\begin{array}{l}\text { Number of fines related to economic sanction } \\
\text { violations }\end{array}$ & $\begin{array}{l}\text { Authors' calculation using Violation } \\
\text { Tracker / Regulatory agency data }\end{array}$ \\
\hline N.Fine_Market & Number of fines related to market violations & $\begin{array}{l}\text { Authors' calculation using Violation } \\
\text { Tracker / Regulatory agency data }\end{array}$ \\
\hline N.Fine_Admin & $\begin{array}{l}\text { Number of fines related to administrative } \\
\text { violations }\end{array}$ & $\begin{array}{l}\text { Authors' calculation using Violation } \\
\text { Tracker / Regulatory agency data }\end{array}$ \\
\hline Fine & Fine amount (total) in a bank-year (\$) & $\begin{array}{l}\text { Violation Tracker / Regulatory agency } \\
\text { websites }\end{array}$ \\
\hline Ln(Fine) & $\operatorname{Ln}(1+$ Fine $)$ & $\begin{array}{l}\text { Authors' calculation using Violation } \\
\text { Tracker / Regulatory agency data }\end{array}$ \\
\hline Fine_Banking & $\begin{array}{l}\text { Amount of fines related to banking business } \\
\text { violations (\$) }\end{array}$ & $\begin{array}{l}\text { Authors' calculation using Violation } \\
\text { Tracker / Regulatory agency data }\end{array}$ \\
\hline Fine_Economic & $\begin{array}{l}\text { Amount of fines related to economic sanction } \\
\text { violations }(\$)\end{array}$ & $\begin{array}{l}\text { Authors' calculation using Violation } \\
\text { Tracker / Regulatory agency data }\end{array}$ \\
\hline Fine_Market & Amount of fines related to market violations $(\$)$ & $\begin{array}{l}\text { Authors' calculation using Violation } \\
\text { Tracker / Regulatory agency data }\end{array}$ \\
\hline Fine_Admin & $\begin{array}{l}\text { Amount of fines related to administrative } \\
\text { violations (\$) }\end{array}$ & $\begin{array}{l}\text { Authors' calculation using Violation } \\
\text { Tracker / Regulatory agency data }\end{array}$ \\
\hline D.Fine_Criminal & $\begin{array}{l}\text { Dummy variable equal to } 1 \text { if a fine is } \\
\text { addressed in a criminal court, and } 0 \text { otherwise }\end{array}$ & $\begin{array}{l}\text { Authors' calculation using Violation } \\
\text { Tracker / Regulatory agency data }\end{array}$ \\
\hline D.Fine_Banking & $\begin{array}{l}\text { Dummy variable equal to } 1 \text { if a fine is related to } \\
\text { banking business violations, and } 0 \text { otherwise }\end{array}$ & $\begin{array}{l}\text { Authors' calculation using Violation } \\
\text { Tracker / Regulatory agency data }\end{array}$ \\
\hline D.Fine_Economic & $\begin{array}{l}\text { Dummy variable equal to } 1 \text { if a fine is related to } \\
\text { economic sanction violations, and } 0 \text { otherwise }\end{array}$ & $\begin{array}{l}\text { Authors' calculation using Violation } \\
\text { Tracker / Regulatory agency data }\end{array}$ \\
\hline D.Fine_Market & $\begin{array}{l}\text { Dummy variable equal to } 1 \text { if a fine is related to } \\
\text { market violations, and } 0 \text { otherwise }\end{array}$ & $\begin{array}{l}\text { Authors' calculation using Violation } \\
\text { Tracker / Regulatory agency data }\end{array}$ \\
\hline D.Fine_Admin & $\begin{array}{l}\text { Dummy variable equal to } 1 \text { if a fine is related to } \\
\text { administrative violations, and } 0 \text { otherwise }\end{array}$ & $\begin{array}{l}\text { Authors' calculation using Violation } \\
\text { Tracker / Regulatory agency data }\end{array}$ \\
\hline
\end{tabular}

Corporate governance Female Director

Female Director \% $\Delta$ Female Director $\%$

Critical Mass

Female CEO

Female Chair

Female Leader

Board Size

Ln(Board Size)

Director Tenure

Ln(Director Tenure)

Director Age

Ln(Director Age)

Director Age Diversity
Dummy variable equal to 1 if the gender of at least one board director is female, and 0 otherwise

Fraction of female directors on the board Change in the fraction of female directors on the board

Dummy variable equal to 1 if the number of female directors on the board is at least 3 , and 0 otherwise

Dummy variable equal to 1 if the gender of the chief executive officer (CEO) is female, and 0 if male

Dummy variable equal to 1 if the gender of the chairperson of the board is female, and 0 if male

Dummy variable equal to 1 if the gender of the $\mathrm{CEO}$ and/or the chairperson / president (board leadership) is female, and 0 if male Size of the board (number of board directors) Ln(Board Size)

Average board tenure (years)

Ln(Director Tenure)

Average age of board directors (years)

Ln(Director Age)

Coefficient of variation of directors' age $=$ Standard deviation of directors' age / Director
Authors' calculation using BoardEx data

Authors' calculation using BoardEx data Authors' calculation using BoardEx data

Authors' calculation using BoardEx data

Authors' calculation using BoardEx data

Authors' calculation using BoardEx data

Authors' calculation using BoardEx data

Authors' calculation using BoardEx data

Authors' calculation using BoardEx data Authors' calculation using BoardEx data Authors' calculation using BoardEx data

Authors' calculation using BoardEx data 
CEO Tenure

Ln(CEO Tenure)

CEO Age

Ln(CEO Age)

CEO Turnover

Foreign Director \%

Employee Representative \%

\section{Bank-specific controls}

Total Assets

Size

$R O E$

Stock Return Volatility

Tobin's $Q$

Ln(Tobin's $Q$ )

Size $Q_{i}$

Size $Q_{234}$

Low Risk Bank

High Risk Bank

Country-specific controls Gender Index Score

Gender Index Rank

GDP Growth

G10
Age

Tenure of the CEO (years)

$\operatorname{Ln}(C E O$ Tenure $)$

Age of the CEO (years)

$\mathrm{Ln}(C E O$ Age $)$

Dummy variable equal to 1 if the CEO in year $t$ is different from the CEO in year $t-1$, and 0 otherwise

Fraction of foreign directors on the board

Fraction of employees on the board

Total assets (euro)

Ln(Total Assets)

Return on equity

Annualised standard deviation of daily stock returns (3-year moving average)

Tobin's Q $=$ (Total assets - Equity + Market value of equity) / Total assets

$\operatorname{Ln}($ Tobin's $Q)$

Dummy variable equal to 1 if a bank's size (total assets) falls into the $1^{\text {st }}$ (top) quartile of the sample, and 0 otherwise

Dummy variable equal to 1 if a bank's size (total assets) falls into the $2^{\text {nd }}-4^{\text {th }}$ (bottom) quartiles of the sample, and 0 otherwise Dummy variable equal to 1 if a bank's average stock price volatility is below the $75^{\text {th }}$ percentile of the sample, and 0 otherwise

Dummy variable equal to 1 if a bank's average stock price volatility is equal to or above the $75^{\text {th }}$ percentile of the sample, and 0 otherwise

Country gender gap index score

Country ranking based on Gender Index Score

GDP real growth rate

Dummy variable equal to 1 if a bank is headquartered in a G10 country, and 0 otherwise
Authors' calculation using BoardEx data Authors' calculation using BoardEx data Authors' calculation using BoardEx data Authors' calculation using BoardEx data Authors' calculation using BoardEx data

Authors' calculation using BoardEx data Authors' calculation using BoardEx data

Orbis Bank Focus

Authors' calculation using Orbis Bank Focus data

Authors' calculation using Orbis Bank

Focus data

Authors' calculation using Thomson Eikon data

Authors' calculation using Orbis Bank Focus and Thomson Eikon data Authors' calculation using Orbis Bank Focus and Thomson Eikon data

Authors' calculation using Orbis Bank

Authors' calculation using Orbis Bank

Authors' calculation using Orbis Bank

Authors' calculation using Orbis Bank

World Economic Forum Global Gender Gap Report 2018

Authors' calculations using the World Economic Forum Global Gender Gap Report 2018

International Monetary Fund (IMF)

Authors' calculation

The table provides definitions of the variables used in the analysis and the source of the data. 
Appendix C: Correlation matrix.

\begin{tabular}{|c|c|c|c|c|c|c|c|c|c|c|c|c|c|c|c|c|}
\hline Variables & $(1)$ & $(2)$ & (3) & (4) & $(5)$ & $(6)$ & $(7)$ & $(8)$ & (9) & $(10)$ & $(11)$ & $(12)$ & (13) & (14) & $(15)$ & $(16)$ \\
\hline (1) Female Director \% & 1.00 & & & & & & & & & & & & & & & \\
\hline (2) $\Delta$ Female Director $\%$ & $0.29 *$ & 1.00 & & & & & & & & & & & & & & \\
\hline (3) Female Leader & $0.33 *$ & 0.01 & 1.00 & & & & & & & & & & & & & \\
\hline (4) Ln(Board Size) & -0.04 & -0.03 & 0.06 & 1.00 & & & & & & & & & & & & \\
\hline (5) Ln(Director Tenure) & 0.07 & 0.01 & 0.01 & 0.03 & 1.00 & & & & & & & & & & & \\
\hline (6) $\operatorname{Ln}($ Director Age $)$ & 0.02 & -0.01 & $-0.13 *$ & $0.14 *$ & $0.34 *$ & 1.00 & & & & & & & & & & \\
\hline (7) $\operatorname{Ln}($ CEO Tenure $)$ & -0.02 & -0.04 & -0.02 & -0.05 & $0.44 *$ & $0.21 *$ & 1.00 & & & & & & & & & \\
\hline (8) $\operatorname{Ln}(C E O$ Age $)$ & -0.06 & -0.04 & $-0.13 *$ & $0.17^{*}$ & $0.24 *$ & $0.36^{*}$ & $0.38 *$ & 1.00 & & & & & & & & \\
\hline (9) CEO Turnover & 0.01 & 0.00 & 0.01 & 0.03 & $-0.23^{*}$ & $-0.12 *$ & $-0.68^{*}$ & $-0.18^{*}$ & 1.00 & & & & & & & \\
\hline (10) Size & $0.27 *$ & 0.04 & $0.19 *$ & $0.37 *$ & -0.06 & $0.23 *$ & $-0.14 *$ & 0.08 & 0.03 & 1.00 & & & & & & \\
\hline (11) $R O E$ & 0.02 & -0.09 & -0.02 & $-0.20 *$ & $0.21 *$ & $-0.19 *$ & $0.12 *$ & $-0.18 *$ & $-0.12 *$ & $-0.21 *$ & 1.00 & & & & & \\
\hline (12) Stock Return Volatility & $-0.18 *$ & -0.04 & -0.04 & 0.08 & $-0.26 *$ & 0.03 & $-0.12 *$ & 0.02 & 0.08 & $0.22 *$ & $-0.43 *$ & 1.00 & & & & \\
\hline (13) Ln(Tobin's $Q)$ & $-0.10^{*}$ & -0.05 & $-0.12 *$ & $-0.20 *$ & $-0.23 *$ & 0.07 & 0.01 & -0.03 & -0.03 & 0.09 & -0.02 & $0.12 *$ & 1.00 & & & \\
\hline (14) Gender Index Rank & $0.44 *$ & 0.01 & $0.21 *$ & $-0.13 *$ & 0.03 & $-0.12 *$ & 0.01 & $-0.14 *$ & -0.02 & $0.34 *$ & $0.17 *$ & $-0.15^{*}$ & 0.01 & 1.00 & & \\
\hline (15) GDP Growth & $0.16^{*}$ & 0.04 & $0.16^{*}$ & $-0.13 *$ & 0.02 & -0.07 & -0.08 & $-0.18^{*}$ & 0.04 & -0.07 & $0.28 *$ & $-0.34 *$ & -0.03 & $0.12 *$ & 1.00 & \\
\hline (16) G10 & $0.24 *$ & $0.12 *$ & -0.03 & 0.03 & $-0.21 *$ & $0.09 *$ & $-0.22 *$ & $-0.10 *$ & 0.06 & $0.32 *$ & -0.07 & 0.02 & $0.17 *$ & $0.26^{*}$ & $-0.15^{*}$ & 1.00 \\
\hline
\end{tabular}

The table reports the correlation matrix for the variables used in the baseline regression analysis. ${ }^{*}$ shows significance at the 1 percent level. Definitions of the variables are provided in Appendix B. 